\title{
Disposal and Treatment Methods for Pesticide Containing Wastewaters: Critical Review and Comparative Analysis
}

\author{
Mariam T. Al Hattab, Abdel E. Ghaly \\ Department of Process Engineering and Applied Sciences, Faculty of Engineering, Dalhousie University, Halifax, Canada. \\ Email: abdel.ghaly@dal.ca
}

Received February $27^{\text {th }}, 2012$; revised March $28^{\text {th }}, 2012$; accepted April $27^{\text {th }}, 2012$

\begin{abstract}
Pesticides provide the primary means for controlling organisms that compete with man for food and fibre or cause injury to man, livestock and crops. They played a vital role in the economic production of wide ranges of vegetable, fruit, cereal, forage, fibre and oil crops which now constitute a large part of successful agricultural industry in many countries. After application to the target areas, pesticide residues are removed from applicators by rinsing with water which results in the formation of a toxic wastewater that represents a disposal problem for many farmers. Pesticides can adversely affect people, pets, livestock and wildlife in addition to the pests they are intended to destroy. The phenomenon of biomagnification of some pesticides has resulted in reproductive failure of some fish species and egg shell thinning of birds such as peregrine falcons, sparrow hawk and eagle owls. Pesticide toxicity to humans include skin and eye irritation and skin cancer. Therefore, care must be exercised in the application, disposal and treatment of pesticides. Currently, disposal of pesticide wastewater is carried out by: 1) land cultivation, 2) dumping in soil pits, plastic pits and concrete pits or on land and in extreme cases in streams near the rinsing operation, 3) use of evaporation beds and 4) land filling. These methods of disposal are unsafe as the surface run off will reach streams, rivers and lakes and the infiltration of the wastewater into the local soil will eventually reach ground water. The treatment methods currently used for pesticide wastewater include: 1) incineration (incinerators and open burning), 2) chemical treatments $\left(\mathrm{O}_{3} / \mathrm{UV}\right.$, hydrolysis, Fenton oxidation and KPEG), 3) physical treatments (inorganic, organic absorbents and activated carbon) and 4) biological treatments (composting, bioaugmentation and phytoremediation). Therefore, the choice of safe, on farm disposal techniques for agricultural pesticides is very important. A comparative analysis was performed on 18 methods of pesticide disposal/treatment using six criteria: containment, detoxification ability, cost, time, suitability for on farm use, size and evaporation efficiency. The results indicated that of the 18 methods evaluated, 9 scored above 80/100 and can be used on farm. They were organic absorbents (97), composting (94), bioaugmentation (92), inorganic absorbents (90), Fenton oxidation (86), $\mathrm{O}_{3} / \mathrm{UV}(83)$, activated carbon (82), hydrolysis (82), and land cultivation (80). The other methods are not suitable for on farm use as they suffered from containment problems, high cost and variability of effectiveness.
\end{abstract}

Keywords: Pesticides; Health; Soil; Water; Disposal; Treatment; Land Cultivation; Disposal Pits; Evaporation Ponds; Landfills; Incineration; $\mathrm{O}_{3} / \mathrm{UV}$; Fenton Oxidation; Hydrolysis; Bioremediation; Bioaugmentaion

\section{Introduction}

Pesticides provide the primary means for controlling organisms that compete with man for food and fibre or cause injury to man, livestock and crops. They are classified based on the pest they control as shown in Table 1. Pesticide expenditures account for $13 \%-22 \%$ of total costs of production per hector. The worldwide pesticide consumption and expenditures in 2007 (Table 2) were 2.37 billion $\mathrm{kg}$ and 39.4 billion dollars, respectively [1]. Table 3 illustrates the top 10 countries applying higher rates $(\mathrm{kg} /$ hectare) of pesticides [2]. Ten companies (Table 4) account for $87.2 \%$ of the total sales [3].

Pesticides played a vital role in the economic produc- tion of wide ranges of vegetable, fruit, cereal, forage, fibre and oil crops which now constitute a large part of successful agricultural industry in many countries. They lower crop losses, increase revenue to farmers from the additional marketable yield obtained with their use and thus lower the cost of production per unit output [4]. Other benefits include: 1) reduced uncertainty of crop loss from pests, 2) increased profit to farm input suppliers (machinery, fertilizer, chemicals and seed companies) from increased sale, 3 ) benefit to consumers through decreased price of raw foods or improved quality of food products and 4) benefit to society as whole (farmers, consumers, farm suppliers, food processors) from increased employment opportunities and expanded export 
Table 1. Common types of pesticides.

\begin{tabular}{ll}
\hline Pesticide & Pest to be controlled \\
\hline Insecticide & Insects \\
Herbicide & Undesirable plants \\
Rodenticide & Rats, mice and other rodents \\
Nematicide & Nematodes \\
Fungicide & Fungal diseases \\
Acasicide & Mites and spiders \\
Bactericide & Bacteria \\
\hline
\end{tabular}

Table 2. 2007 worldwide consumption and expenditures of pesticide active ingredients [1].

\begin{tabular}{ccc}
\hline Pesticide & Consumption $\mathbf{( \mathbf { 1 0 } ^ { \mathbf { 6 } } \mathbf { ~ k g } )}$ & Expenditures $\mathbf{( \mathbf { 1 0 } ^ { \mathbf { 6 } } \mathbf { \$ } )}$ \\
\hline Herbicides & 955 & 15,512 \\
Insecticide & 405 & 11,158 \\
Fungicide & 235 & 9216 \\
Other $^{*}$ & 775 & 3557 \\
Total & $\mathbf{2 3 7 0}$ & $\mathbf{3 9 , 4 4 3}$ \\
\hline
\end{tabular}

*Other includes mematicide, fumigants and other miscellaneous.

Table 3. Top 10 countries applying pesticide at higher rates in 2000 [2].

\begin{tabular}{lc}
\hline Country & Application Rate (kg/ha) \\
\hline Costa Rica & 51.2 \\
Colombia & 16.2 \\
Japan & 12.0 \\
Netherlands & 9.4 \\
Korea & 6.6 \\
Ecuador & 6.0 \\
Portugal & 5.3 \\
France & 4.6 \\
Greece & 2.8 \\
Uruguay & 2.7 \\
\hline
\end{tabular}

Table 4. Top 10 pesticide companies in 2007 [3].

\begin{tabular}{lccc}
\hline Company & Country & $\begin{array}{c}\text { Sales } \\
\left.\mathbf{( 1 0 ^ { 6 }} \mathbf{\$}\right)\end{array}$ & $\begin{array}{c}\text { Market Share } \\
\mathbf{( \% )}\end{array}$ \\
\hline Bayer & Germany & 7458 & 19.0 \\
Syngenta & Switzerland & 7285 & 18.5 \\
BASF & Germany & 4297 & 10.9 \\
Dow Agro Science & USA & 3779 & 9.6 \\
Monsanto & USA & 3599 & 9.1 \\
Du Pont & USA & 2369 & 6.0 \\
Makhteshim Agan & Israel & 1895 & 4.8 \\
Nufarm & Australia & 1470 & 3.7 \\
Sumitomo Chemical & Japan & 1209 & 3.0 \\
Aystra Life Science & Japan & 1035 & 2.6 \\
Total & N/A & $\mathbf{3 4 , 3 9 6}$ & $\mathbf{8 7 . 2}$ \\
\hline
\end{tabular}

Sales are in millions of dollars; Total Worldwide Sales $=39443$. of food products $[5,6]$. The benefit/cost ratio vary from 4 to 33 (for every dollar spent on pesticide farmers receive an additional $\$ 4-33$ in revenue) depending upon crop rotation and year $[4,7]$.

After pesticides are applied to the target areas, pesticide residues remain in containers and application equipment. These residues are removed from applicators by rinsing with water which results in the formation of a toxic wastewater that can adversely affect people, pets, livestockand wildlife [8-10]. The resulting ecological impact of unsafe disposal of pesticides can be severe depending on the type of pesticide and the amount contained in the wastewater. The phenomenon of biomagnification of some pesticides has resulted in reproductive failure of some fish species [11,12] and egg shell thinning of birds such as peregrine falcons, sparrow hawk and eagle owls [13]. Pesticide toxicity to humans include skin and eye irritation and skin cancer [14]. Therefore, care must be exercised in the application, disposal and treatment of pesticides. Currently, disposal of pesticide wastewater is carried out by several methods including: 1) land cultivation, 2) dumping in soil pits, in ditches, in lagoons, on land, and in extreme cases in sewers and streams near the rinsing operation, 3) use of evaporation pond and 4) land filling. These methods of disposal are totally unsafe. The surface run off will reach streams, rivers and lakes and the infiltration of the wastewater into the local soil will eventually end up in the ground water. The treatment methods currently used for pesticide containing wastewater include: 1) incineration, 2) chemical treatment, 3) physical treatment and 4) biological treatment. These treatment methods either require land or are expensive and suffer from variability of effectiveness [15]. Thus, the development and selection of safe, on farm disposal/treatment technique for agricultural pesticides is paramount.

The aim of this study was to review the current methods of disposal and treatment of pesticides and to perform a comparative analysis to determine the most appropriate method for on farm use.

\section{Pesticide Disposal Methods}

The methods for the disposal of low level pesticides (Table 5) include: land cultivation, disposal pits, evaporation ponds and landfills [16-20]. There are three types of disposal pits: soil pit, plastic pit and concrete pit.

\subsection{Land Cultivation}

In this method, excavated contaminated soil is spread out in a thin layer on uncontaminated soil (Figure 1) in order to allow for natural chemical and biological processes to transform and degrade the contaminants. Soil contains microbes (fungi, algae and bacteria) capable of 
Table 5. Disposal methods of pesticide containing wastewater.

\begin{tabular}{|c|c|c|c|}
\hline Method & Description & Advantages & Disadvantages \\
\hline Land Cultivation & $\begin{array}{l}\text { Place liquid wastes in plow } \\
\text { zone of soil for subsequent } \\
\text { weathering }\end{array}$ & $\begin{array}{l}\text { On-site use } \\
\text { Simple technology }\end{array}$ & $\begin{array}{l}\text { Land requirements } \\
\text { Possible runoff and leaching } \\
\text { Slow and variable decomposition } \\
\text { Restricted vegetation }\end{array}$ \\
\hline Disposal Pits & $\begin{array}{l}\text { Place liquid wastes in pits } \\
\text { containing soil and open to air } \\
\text { for subsequent weathering }\end{array}$ & $\begin{array}{l}\text { On-site use } \\
\text { Simple technology } \\
\text { Secure containment }\end{array}$ & $\begin{array}{l}\text { Slow decomposition } \\
\text { Limited lifetime of pit } \\
\text { Effectiveness varies with climate }\end{array}$ \\
\hline Evaporation Ponds & $\begin{array}{l}\text { Place liquid wastes in lined } \\
\text { ponds open to air for } \\
\text { subsequent weathering }\end{array}$ & $\begin{array}{l}\text { On-site use } \\
\text { Simple technology } \\
\text { Secure containment }\end{array}$ & $\begin{array}{l}\text { Slow decomposition } \\
\text { Limited lifetime of pond effectiveness } \\
\text { Varies with climate }\end{array}$ \\
\hline Landfills & Burial of wastes in soil & $\begin{array}{l}\text { Generally available } \\
\text { Complete removal }\end{array}$ & $\begin{array}{l}\text { Land requirements } \\
\text { High transportation costs } \\
\text { Possible runoff and leaching }\end{array}$ \\
\hline
\end{tabular}

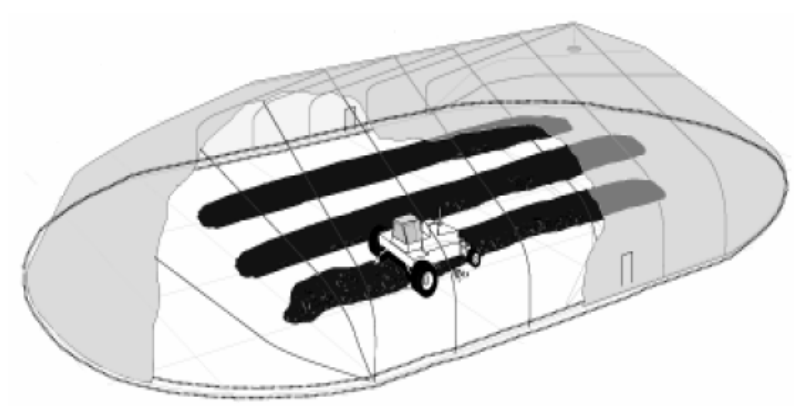

Figure 1. Land cultivation of contaminated soil [21].

metabolizing pesticides $[22,23]$. The ability of bacteria to metabolize pesticides has been well documented by several researchers. Bhadhade et al. [24] reported that soil bacteria was capable of degrading $83 \%-93 \%$ of the organo-phosphorouspesticide monocrotophos. Ohshiro et al. [25] reported a $96 \%$ reduction in isoxathion from the organophosphouruspestiside by bacteria isolated from turf green soil. Kearney et al. [26] reported that soil microbes were capable of degrading $90 \%$ of the alachlor pesticide within 30 - 40 days. Tang and You [27] reported that the triazophos bacteria was capable of degrading $33.1 \%-95.8 \%$ of pesticides in soil.

Racke and Coats [28] reported that after soil has been treated with a pesticide a few times its microorganisms build up a need for that pesticide which results in fairly rapid degradation of any additional applications. Schoen and Winterlin [29] stated that natural soil degradation is effective when low concentrations of the pesticide are present, but with high concentrations of pesticide it becomes much more difficult to degrade. Felsot [30] stated that land cultivation is only effective for compounds that can be biotransofrmed or biominerlized by soil microbes. Somasundaram et al. [31] reported that the ability of soil microbes to degrade certain pesticides is affected by pesticide toxicity to soil microbes that are responsible for the degradation. Felsot et al. [22] stated that land cultivation is effective if the pesticide is degraded at the same or faster rate than it is applied to the field. Felsot et al. [32] noted that land cultivation can be enhanced by the addition of organic amendments such as sewage sludge.

\subsection{Soil Pit}

A primary method for disposing of liquid pesticide waste is by dumping it in an unlined soil evaporation pit (Figure 2), usually $15 \times 15 \times 1 \mathrm{~m}$ [33]. Schoen and Winterlin [29] reported that factors such as chemical structure and concentration of pesticide play a major role in the degradation of pesticides in soil pits. Gan and Koskinen [34] stated that the dissipation of the pesticide decreases as the concentrations of pesticide increases. Dzantor and Felsot [35] and Gan et al. [36] noted that high pesticide concentrations may cause microbial toxicity which would inhibit the degradation of the pesticide.

Several researchers $[22,34,36,37]$ noted that the prolonged dissipation of pesticides opens a window for runoff and leaching, especially at higher pesticide concentrations. Gan et al. [36] reported that $50 \%$ dissipation of the alachlor pesticide in soil, at concentrations of 4 and 4 $300 \mathrm{mg} / \mathrm{kg}$ took approximately 2 and 52 weeks, respectively. Gan et al. [38] noted that atrazine pesticide took approximately 4 and 24 weeks to be dissipated to half the concentration of 7 and $6400 \mathrm{mg} / \mathrm{kg}$ in soil, respectively. Schoen and Winterlin [29] noted that captan, trifluralin and diazinon at concentrations of $100 \mathrm{mg} / \mathrm{kg}$ took $1-2$, $116-189$ and $77-160$ weeks to dissipate to half the concentration while captan, trifluralin and diazinon at concentrations of $1000 \mathrm{mg} / \mathrm{kg}$ took $30-48,168-544$ and $77-160$ weeks to reach $50 \%$ disappearance in soil, respectively.

\subsection{Plastic Lined Pit}

This method for disposal of pesticide waste requires proper selection of the site to avoid leaching and runoff. 


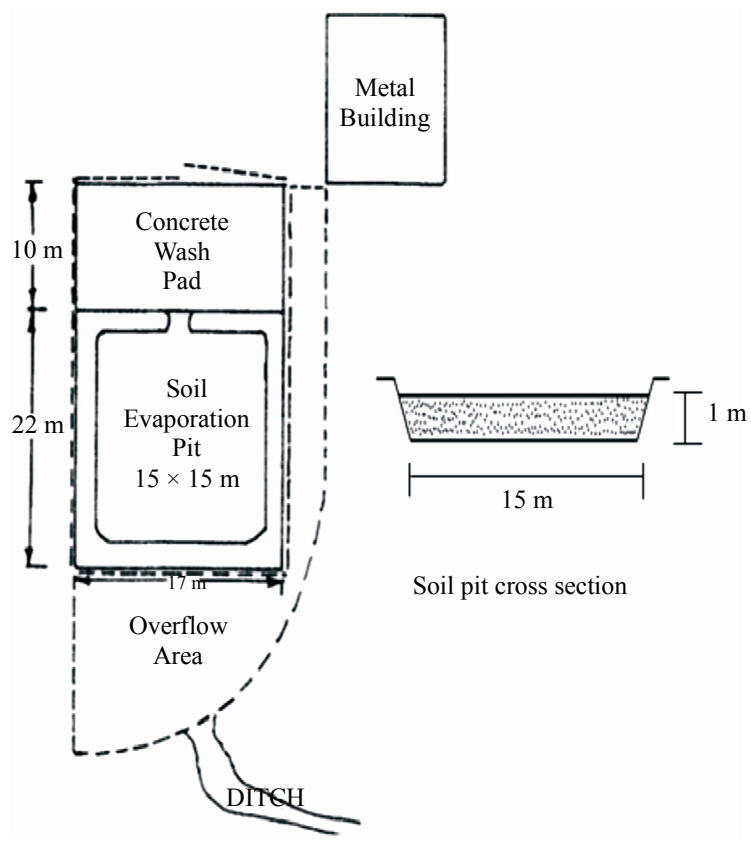

Figure 2. A soil pit for disposal of pesticide water [33].

The site should be in an area where there is no danger of contaminating dwellings groundwater sources and surface water used for crop and livestock production. The pit should be on a levelled ground with a depth of $0.5-1$ $\mathrm{m}$ covered with a plastic liner and a layer of soil is laid on top of the liner (Figure 3). The pit should be open to the atmosphere in order to allow for water evaporation into the atmosphere. A roof cover will prevent the water level from raising due to rain or snow. The wastewater is pumped into the pit for pesticide biodegradation by soil microbes [22]. Hall et al. [20] reported that the presence of microbes in the soil water mixture in plastic lined pits was responsible for the degradation of pesticide and no accumulation of pesticide was noted in the pits. Junk and Richard [39] evaluated the effectiveness of 90,000 L polyethylene lined disposal pit with over $150 \mathrm{~kg}$ of 25 different types of pesticides for over 2 years and concluded that this method was in fact effective for disposal of pesticide waste with insignificant release to air and water surroundings.

Figure 4 illustrates a cross section view of a simple small scale plastic pit used to dispose of pesticide waste. It consists of a plastic drum with a length and width of 75 $\times 55 \mathrm{~cm}$, respectively. Inside the drum is a mixture of 15 $\mathrm{kg}$ of soil and $60 \mathrm{~L}$ of water, that was used to treat pesticide waste which was introduced into the system through the inlet. Junk et al. [19] used 56 plastic containers filled with $15 \mathrm{~kg}$ of soil and $60 \mathrm{~L}$ of water to test the degradation of alachlor, atrazine, triflualin, 2,4-D ester, carbaryl and parathion and found this system not suitable for atrazine but was effective and very rapid for 2,4-D and carbayl. They concluded that: 1) the plastic container

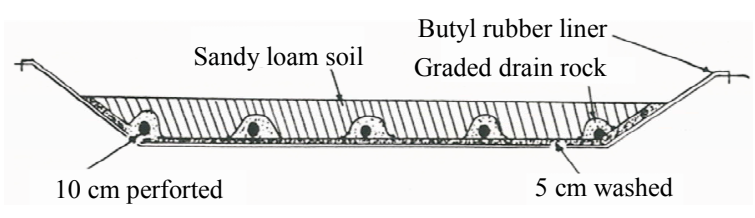

Figure 3. A plastic lined evaporation pit for disposal of pesticide wastewater [16].

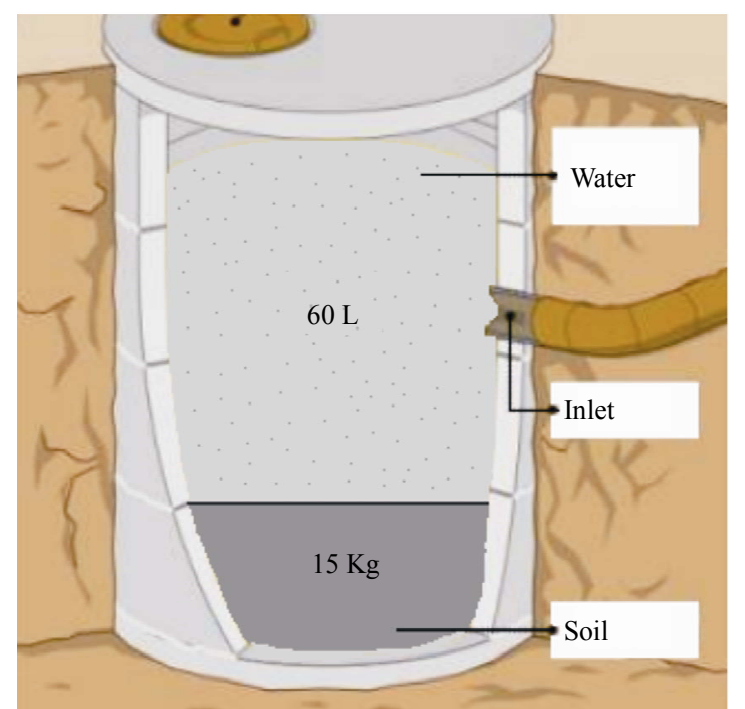

Figure 4. A cross section of a plastic pit for disposal of pesticide wastewater [40].

provided satisfactory containment for most common pesticides, 2) soil was a satisfactory source for microorganisms, 3) aeration and buffers had questionable value, 4) half life concept for degradation was not applicable and 5) sampling from small disposal sites was a problem.

\subsection{Concrete Pit}

Similar to the plastic lined pit, the concrete pit should be on levelled ground with a depth of 0.5 to $1 \mathrm{~m}$, a length of $8-10 \mathrm{~m}$ and a width of $3.5 \mathrm{~m}$ and reinforced with $0.20 \mathrm{~m}$ thick concrete walls. The pit consists of a top and bottom layer of gravel that is $4 \mathrm{~cm}$ in diameter with the middle layer consisting of topsoil (Figure 5). The pit should also have a cover to prevent rise in water level from rain or snow but remain open to the atmosphere in order to allow for water evaporation.

Johnson and Hartman [41] tested the microbiological activity in a concrete pit and concluded that the degradation process in the pit was effective and no long-term accumulation of pesticide was present. Junk and Richard [39] tested the effectiveness of $30,000 \mathrm{~L}$ concrete disposal pit with over $50 \mathrm{~kg}$ of 40 different types of pesticides for 8 years and concluded that this method was in fact effective for disposal of pesticide waste with insignificant release to air and water surroundings. Hall [42] tested the effectiveness of an open concrete disposal pit 
for the degradation of 45 pesticides over five months and concluded that the biodegradation of the pesticides was successfully accomplished and the pit did not leak or pollute the air, but the system was too large and complicated for most farms.

\subsection{Evaporation Beds}

Lined evaporation beds (Figure 6) are used for the disposal of pesticide wastewater. Leach lines underneath the soil surface supply the beds with the pesticide residues from washing equipment. The pesticides rise to the beds surface where they are degraded through photochemical, chemical and biological actions and are distributed via air vapour. Some of the beds have hydrated lime incurporated into the soil in order to aid in the degradation of certain pesticides. A medium scale disposal system of this type costs up to $\$ 50,000$ to construct $[16,22]$.

Hodapp and Winterlin [44] reported a reduction in the diazinon pesticide of $62.54 \%$ using lined evaporation bed without lime and a degradation of $77.75 \%$ with lime. They also reported an ethyl parathion reduction of $69.83 \%$ using lime treatment in the beds and a reduction of $45.45 \%$ without the use of lime. Winterlin et al. [16] tested ten $(6 \times 12 \times 1 \mathrm{~m})$ lined (with a butyl rubbermembrane liner and $36 \mathrm{~cm}$ of sandy loam soil) evaporation beds to determine their pesticide decay effectiveness. Pesticide rainsate was introduced through subsurface tiles in limited amounts and the effects of geography, climate and lime application were examined. The method appeared to be beneficial for disposal of some pesticides but not all. Over 100 pesticides were tested, but only 46 were actually detected.

This method for the disposal of pesticide containing wastewaters is advantageous because the beds are economical, little maintenance is required, do not build up high levels of pesticides and are effective in degrading as well as containing the pesticides without excessive exposure through air vapour $[16,44]$. It is considered an economical, on-site method of disposal which requires only annual monitoring. The disadvantages appear to be the development of a high concentration of residue in the top layer of the soil and the difficulty in acquiring a representative sample [33].

\subsection{Land Filling}

Landfills are sites that dispose of waste by burial into the soil where microorganisms are used to change the composition of the toxic elements. Landfills for pesticides (Figure 7) are equipped with drying pits (Figure 8) containing soil to provide the microbes needed to break down the pesticide components into non harmful elements. A nearby sump for the propose of draining and rinsing the containers that have not been fully emptied or rinsed $[47,48]$.

Munnecke [49] reported that soil bacteria were capable of hydrolyzing ethyl parathion found in pesticide container residues within $16 \mathrm{~h}$. Johnson and Lavy [50] reported that carbofuran, thiobencarb and triclopyr buried in degrading containers dissipated to $50 \%$ of the initial concentration with the first 94 days or less, while benomyl took 179 - 1020 d before 50\% dissipation. They also noted that the rates of dissipation decreased with an increase in soil depth.

Yasuhara et al. [51] detected 190 compounds in landfill leachates in Japan. Williams et al. [52] reported that the pesticide mecoprop is found in landfill leachate because it is resistant to anaerobic degradation. Christensen et al. [53] noted the presence of the pesticide bentazon, $\mathrm{N}, \mathrm{N}-$ Diethyltoluamide and mecoprop in landfill leachate because of their persistence to anaerobic landfill conditions. Alloway and Ayres [54] noted the presence of the pesticides atrazine and simazine in landfill leachate.

\section{Pesticide Treatment Methods}

The pesticides treatment methods (Table 6) include: 1) thermal treatment, 2) chemical treatments, 3) physical

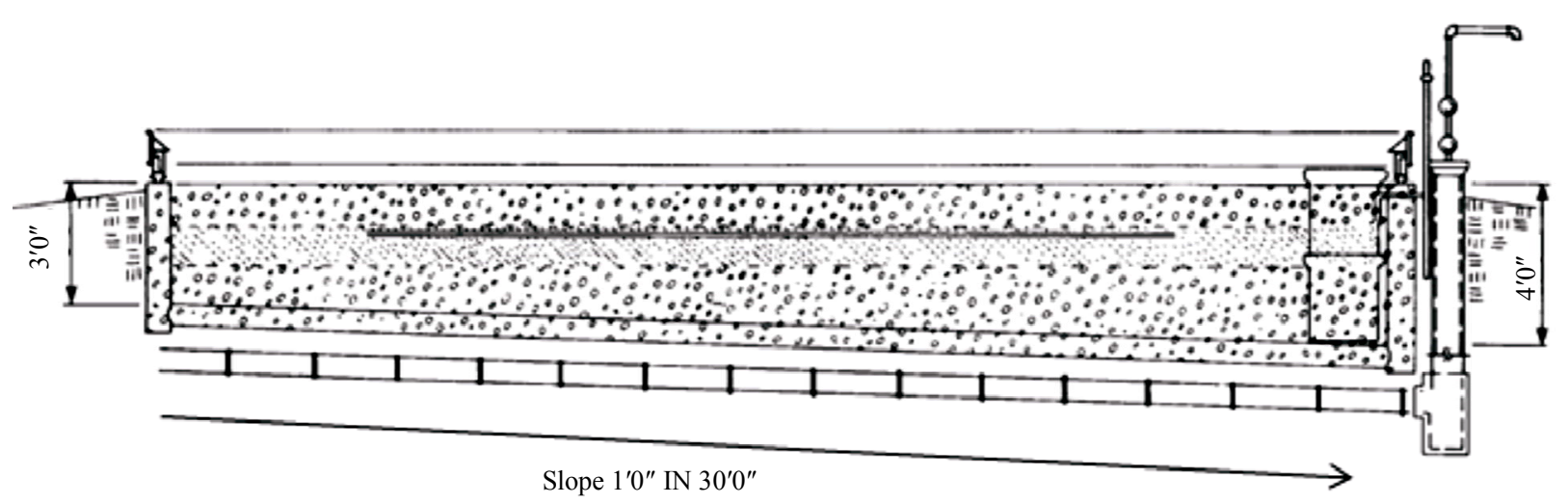

Figure 5. A cross section of concrete pit for disposal of pesticide wastewater [20]. 


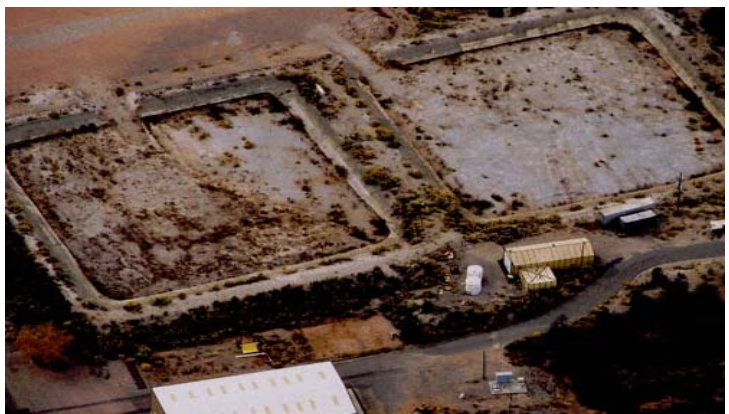

Figure 6. Evaporation beds for disposal of pesticide wastewater [43].

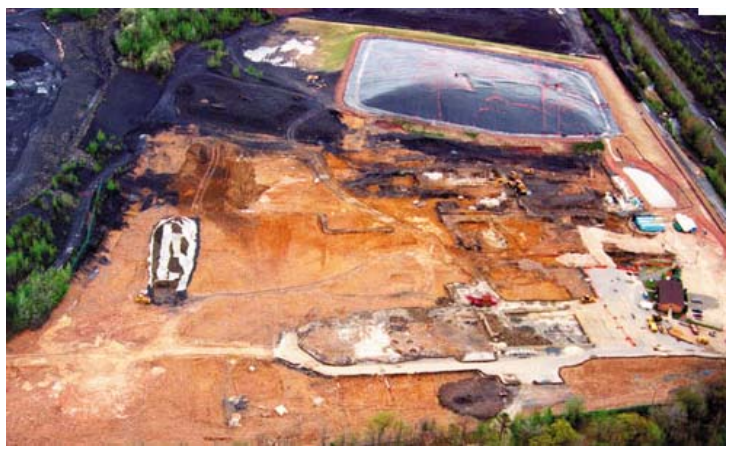

Figure 7. A landfill for disposal of pesticide wastes [45].

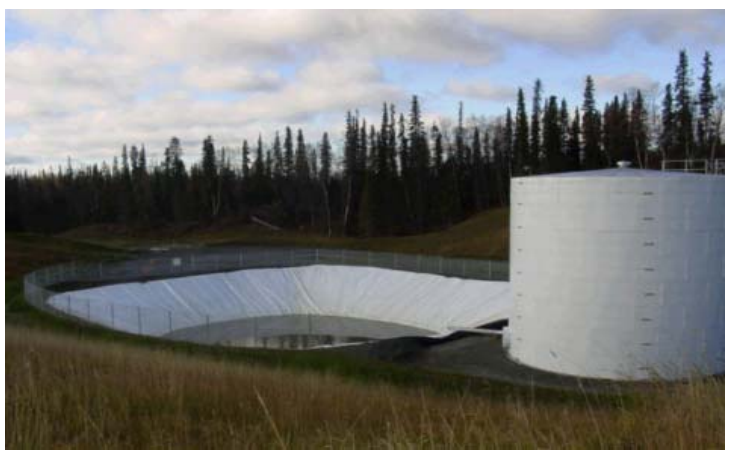

Figure 8. The landfill leachate collection pit [46]. treatments and 4) biological treatments. Thermal treatments include incineration and open burning. Chemical treatments include ozonation/UV radiation, Fentonoxidation, hydrolysis and KPEG. Physical treatments are based on absorption using activated carbon, inorganic and organic materials. Biological treatments include composting, phytoremediation and bioaugmentation.

\subsection{Incineration}

Pesticide Incineration is a high temperature oxidation process where the pesticide is converted into inorganic gases (water vapour, $\mathrm{CO}_{2}$, volatile acids, particles and metal oxides) and ash [22,54]. Incineration of pesticide should be operated at temperatures higher than $1000^{\circ} \mathrm{C}$ so that the pesticide can be treated within the first $2 \mathrm{sec}$ onds. At such temperatures, smoke production is nil and the generated combustion gases are similar to those generated by wood burning [22]. Temperatures lower than $1000^{\circ} \mathrm{C}$ can also be used as long as the incineration time of the pesticide does not exceed 2 seconds [23]. However, lower temperatures tend to produce toxic intermediate products [56].

Kennedy et al. [57] noted change in the combustion efficiency over the temperature range of $600^{\circ} \mathrm{C}-1000^{\circ} \mathrm{C}$. Ferguson and Wilkinson [55] reported that incineration has $99.99 \%$ destruction efficiency at temperatures of $1000^{\circ} \mathrm{C}$ and a retention time of $2 \mathrm{~s}$ in the combustion zone. Steverson [58] reported a 99\% destruction efficiency for 16 currently used insecticides and herbicides at temperatures ranging from $200^{\circ} \mathrm{C}$ to $700^{\circ} \mathrm{C}$. Linak et al. [59] reported an incineration efficiency of greater than 99.99\% for dinoseb. Ahling and Wiberger [60] noted that the incineration of fenitrothion and malathion at temperatures lower than $600{ }^{\circ} \mathrm{C}$ gave emissions of $1 \%-2 \%$ of the pesticide amount added and temperatures above $700^{\circ} \mathrm{C}$ would be required to achieve safe destruction and emission levels.

Table 6. Current treatment methods of pesticide containing wastewater.

\begin{tabular}{|c|c|c|c|}
\hline Method & Description & Advantages & Disadvantages \\
\hline Thermal & $\begin{array}{l}\text { Controlled combustion of either liquid } \\
\text { waste or concentrated residue }\end{array}$ & $\begin{array}{l}\text { Destructive } \\
\text { Rapid } \\
\text { No by-products }\end{array}$ & $\begin{array}{l}\text { High costs } \\
\text { Complex } \\
\text { Not useful for some chemical }\end{array}$ \\
\hline Chemical & $\begin{array}{l}\text { Chemical destruction through use of } \\
\text { oxidative, reductive, hydrolytic or } \\
\text { catalytic reagents }\end{array}$ & $\begin{array}{l}\text { Destructive } \\
\text { Rapid }\end{array}$ & $\begin{array}{l}\text { High costs } \\
\text { Complex } \\
\text { Variable effectiveness }\end{array}$ \\
\hline Physical & $\begin{array}{l}\text { Removal of chemicals from } \\
\text { wastewater by adsorption and/settling }\end{array}$ & $\begin{array}{l}\text { Rapid } \\
\text { Possible on-site use }\end{array}$ & $\begin{array}{l}\text { No destruction involved } \\
\text { By-products for disposal }\end{array}$ \\
\hline Biological & $\begin{array}{l}\text { Use of micro-organisms to destroy } \\
\text { chemicals }\end{array}$ & Destructive & $\begin{array}{l}\text { High costs } \\
\text { Susceptible to shock } \\
\text { Relatively slow } \\
\text { Variable effectiveness }\end{array}$ \\
\hline
\end{tabular}


Incinerators (Figure 9) capable of achieving high levels of destruction are equipped with a combustion chamber, an afterburner, scrubbers and electrostatic filters. Ferguson and Wilkinson [55] reported the following performance standards for incinerating hazardous wastes: 1) the incinerator must achieve a destruction and removal efficiency greater than $99.99 \%$ for each of the chemicals present in the waste feed, 2) $\mathrm{HCl}$ emissions must not exceed $1.8 \mathrm{~kg} / \mathrm{h}$ or $1 \%$ of the $\mathrm{HCl}$ in the stack gas prior to entering any pollution control equipment and 3) the particulate matter emitted must not exceed 180 $\mathrm{mg} / \mathrm{DSCM}$ when corrected to $7.0 \% \mathrm{O}_{2}$. The advantages of incineration include: 1) effectiveness in degrading chlorinated organics, 2) destruction efficiency of $99.99 \%$ and 3) setup at locations next to plants generating the waste. The disadvantages of incineration technology include: 1) need for sophisticated equipment 2) production of cyanide in the off gas during the incineration of organonitrogen pesticides, 3) too costly and complex, 4) it is intended for centralized large scale disposal and 5) not recommended for inorganic pesticides [22].

\subsection{Open Burning}

This method combusts pesticides and pesticide waste containers by piling up empty paper and plastic containers and setting them on fire (Figure 10). Although this method is inexpensive and convenient, it is hazardous to workers, plants and animals. It is prohibited in some cases by the Regional Air Quality regulations in the US [1]. It emits gases, smoke and fumes into the atmosphere as well as toxic residues that are left in the containers.
Adebona et al. [63] noted several products of incomeplete combustion, polyaromatic hydrocarbons and low levels of dioxins in open burning tests on $22.7 \mathrm{~kg}$ insecticide bags. Oberacker et al. [64] noted that after burning bags containing phorate, $2 \%$ of the phorate was released into the air and $0.5 \%$ remained in the solid residues. Felsot et al. [22] reported that bags containing atrazine released $13 \%$ of the remaining product into the air while $25 \%$ remained as residue. Such results indicate that the temperatures for complete combustion were not reached or were not maintained long enough in order to obtain destruction efficiencies of $99.99 \%$ or greater [22].

\subsection{Ozonation/UV Radiation}

The use of ozone and UV radiation to enhance the oxidation of aromatic compounds was investigated by several researchers $[17,28,65]$. Ozonation is more effective treatment method in the presence of UV light because it canform hydrogen radicals which are very effective oxidizing agents $[66,67]$. The benefits of this process are its mobility, ease of operation and rapid effects. The disadvantages are its high energy consumption and initial equipment cost [18].

Kuo [68] used a UV/ozonation system (Figure 11) consisting of a medium-pressure mercury vapor lamp with a water cooling jacket and an ozone generator. The lamp power consumption was $150 \mathrm{~W}$ and was capable of $14.3 \mathrm{~W}$ output (at $3.0 \mathrm{~mW} / \mathrm{cm}^{2}$ at a distance of $9 \mathrm{~cm}$ ). The $\mathrm{O}_{3}$ was pumped at a rate of $400 \mathrm{mg} \mathrm{O} / \mathrm{hr} / \mathrm{L}$ solution. A solution of $2 \% \mathrm{KI}$ was used for absorbing the residual ozone from the reactor.

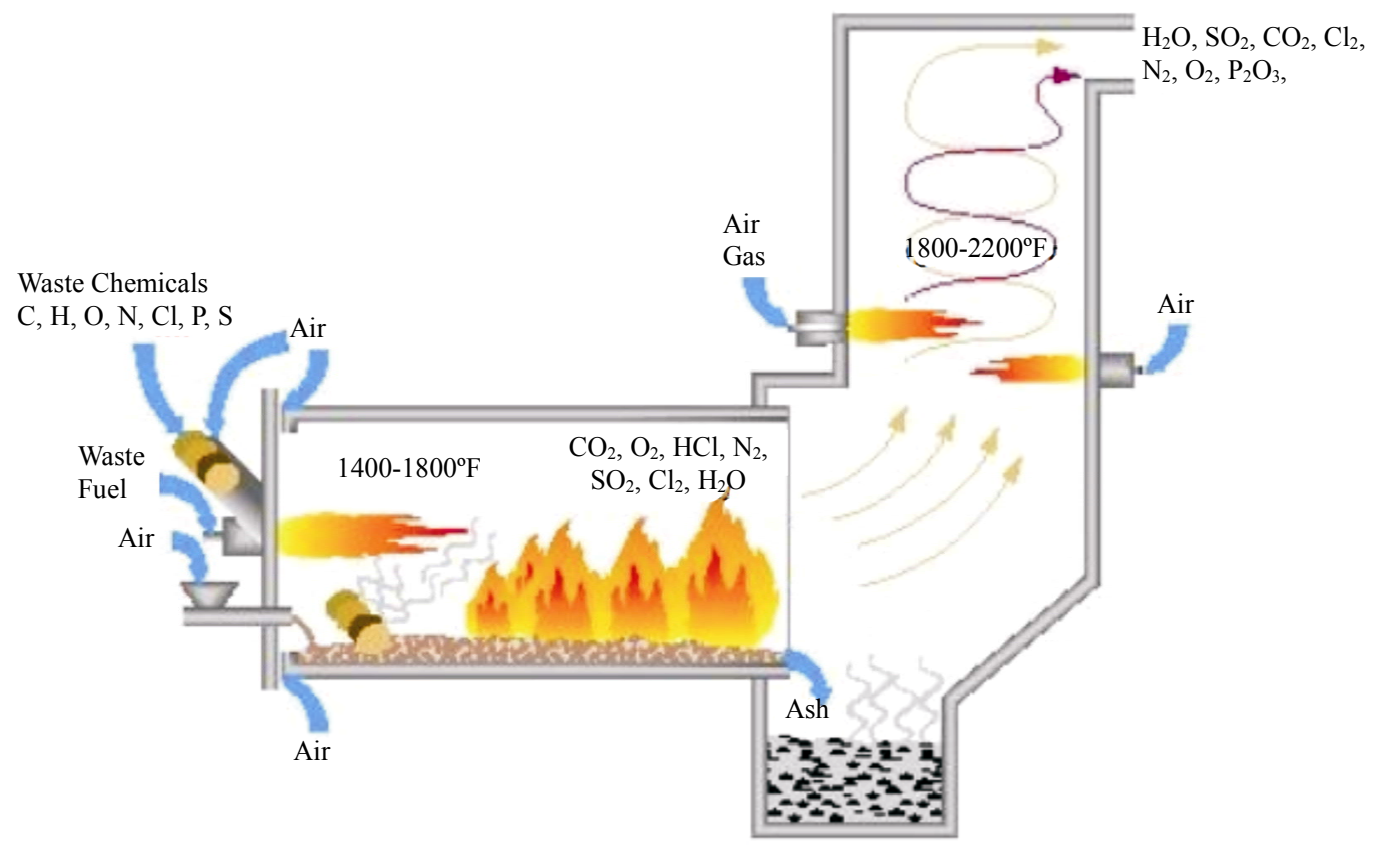

Figure 9. An incinerator for pesticide wastes [61]. 


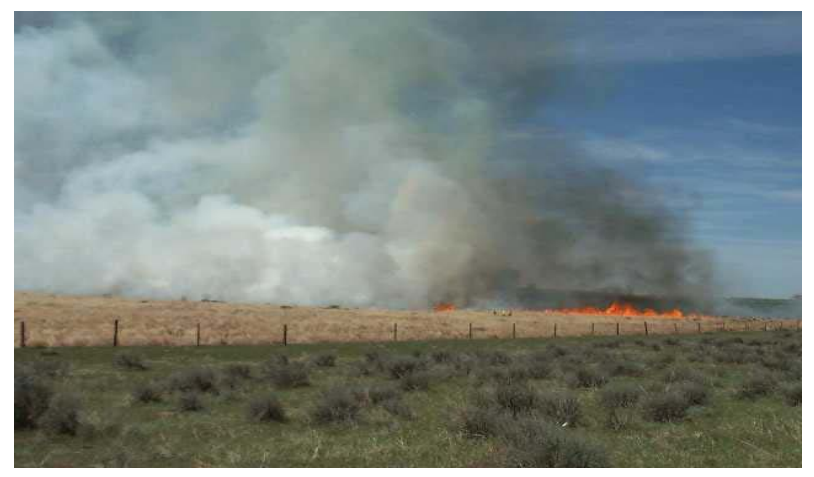

Figure 10. Open burning of pesticide wastes [62].

Somlich et al. [17] noted that irradiation of the alachlor pesticide achieved de-chlorination of the compound, while ozonation works to oxidize the compound into several intermediate products. Under Ultraviolet irradiation, the photon absorption by the carbonyl present in the compound is then followed by the loss of the chlorine. The pesticide degradation reactions that take place under UV/ozonation are as follow [69]:

$$
\begin{aligned}
& \text { pesticide }+\mathrm{O}_{3} \underset{\mathrm{H}_{2} \mathrm{O}}{\stackrel{\text { UV light }}{\longrightarrow}} \mathrm{CO}_{2}+\mathrm{H}_{2} \mathrm{O}+\text { simple species } \\
& \text { simple species } \stackrel{\text { microbes }}{\longrightarrow} \mathrm{CO}_{2}+\mathrm{H}_{2} \mathrm{O}+\text { other gases }
\end{aligned}
$$

Kearney et al. [18] monitored the degradation of alachlor using a $\mathrm{UV} / \mathrm{O}_{3}$ system by measuring the concentration of the $14 \mathrm{CO}_{2}$ released. Under UV radiation, the alachlor pesticide was completely depleted from the water with the presence of oxygen within 25 minutes while it and took 50 minutes before it was fully depleted with ozone alone.

\subsection{Fenton Oxidation}

The Fenton process can be used as part of an oxidative system (Figure 12) to treat and degrade pesticides. It consists of hydrogen peroxide $\left(\mathrm{H}_{2} \mathrm{O}_{2}\right)$ and iron salts at low pHs [71]. The iron salts act as a catalyst, increasing the effectiveness of the $\mathrm{H}_{2} \mathrm{O}_{2}$ by forming highly reductive hydroxyl radicals. The radicals are capable of oxidizing other species that are present in the solution as follows [72].

$$
\begin{aligned}
& \mathrm{H}_{2} \mathrm{O}_{2}+\mathrm{Fe}^{2+} \rightarrow \mathrm{Fe}^{3+}+\mathrm{OH}^{-}+\mathrm{OH}^{\bullet} \\
& \mathrm{OH}^{\cdot}+\mathrm{RH} \stackrel{\text { Pesticide species }}{\longrightarrow} \mathrm{R}^{\cdot}+\mathrm{H}_{2} \mathrm{O}
\end{aligned}
$$

Hydroxyl radicals are very powerful oxidizing agents with a $2.33 \mathrm{~V}$ oxidative potential [72]. The rate of degradation of organic pollutants is strongly accelerated by UV irradiation. The photolysis of the $\mathrm{Fe}^{3+}$ complexes allows the regeneration of $\mathrm{Fe}^{2+}$ thus allowing the reaction to proceed much quicker in the presence of $\mathrm{H}_{2} \mathrm{O}_{2}$ [73]. The advantages of this method for pesticide treatment are: low cost, ease of operation, simplicity and the wide range of temperature that can be used [72].

Fallmann et al. [70] noted a $72 \%$ reduction in $100 \mathrm{ppm}$

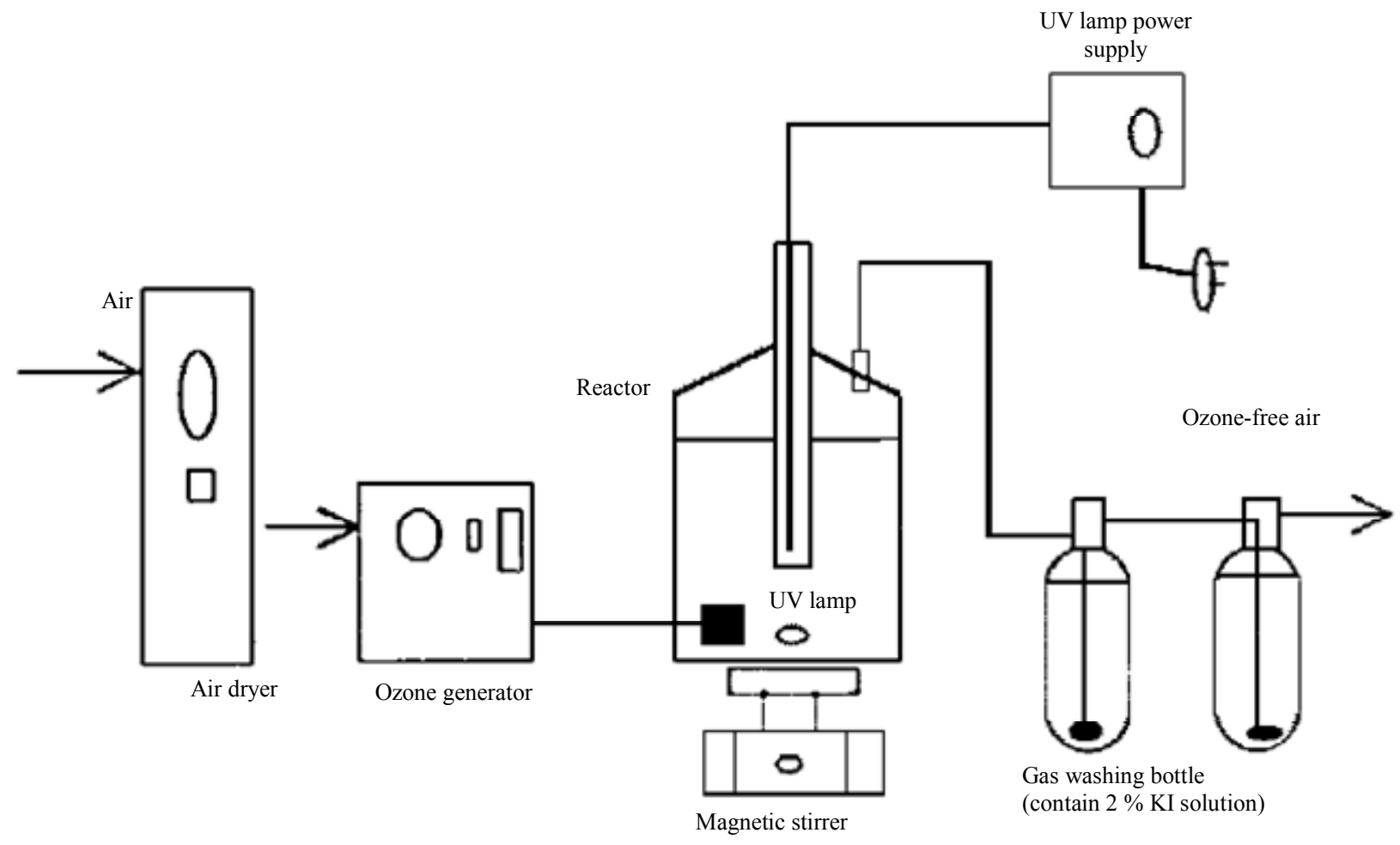

Figure 11. A $\mathrm{UV} / \mathrm{O}_{3}$ system for the treatment of pesticide wastewater [68]. 


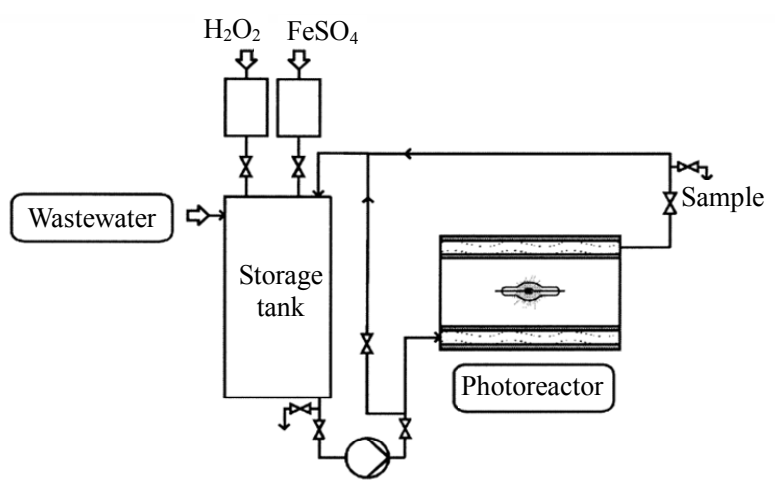

Figure 12. A photo assisted Fenton system for treatment of pesticide wastewater [70].

total organic carbon solution using $23 \mathrm{~mL}$ of hydrogen peroxide and a reaction time of 124 minutes in a photo assisted Fenton process. Larson et al. [74] reported that in the presence of ferric perchlorate and a mercury lamp, the atrazine pesticide had a half-life of less than 2 minutes compared to 1500 minutes when iron salt was not present. Huston and Pignatello [75] noted a half-life of less than 10 minutes for the captanpesticide using UV assisted Fenton reagent at a $\mathrm{pH}$ of 2.8. Pignatello and Sun [76] reported a half-life of 2 minutes for methyl parathion using UV assisted Fenton reagent. Doong and Chang [77] reported a half-life of less than 10 minutes for alachlor pesticide under photo assisted Fenton reagent at a $\mathrm{pH}$ of 2.8 .

\subsection{Hydrolysis}

This method for pesticide treatment works by hydrolyz- ing the ester linkages found in pesticide compounds, including pyrethroids, carbamates, organophosphates and acetaniledes. These compounds can be hydrolyzed in solutions with high $\mathrm{pH}$ levels [22]. Desmarchelier [78] used calcium hydroxide for ester hydrolysis and found it to be a safer alternative to sodium and potassium hyoxides for the hydrolysis of fenitrothion pesticide. Lee et al. [79] noted that under basic conditions, sodium perborate was more effective in the hydrolysis of organophosorus than sodium hydroxide, because the peroxide anion released from sodium perborate is much more reactive to organophosphorus than the hydroxyl ion. Qian et al. [80] noted an enhancement in the hydrolysis process of mevinphos, diazinon, methyl parathion, malathion and parathion in lake water $(10 \mathrm{mg} / \mathrm{L})$ using sodium perborate at $\mathrm{pH}$ of 9.88. However, with the presence of soil, the reaction was noted to be significantly slower and the concentration of perborate had to be increased by four folds.

Metal oxide and divalent metal ions have been noted for their ability to catalyze the hydrolysis of organphosorus insecticides. Smolen and Stone [81] reported that the phophorothionate insecticides (chlorpyrifos-methyl, zinophos, diazinon, parathion-methyl and runnel) and phosphorooxonates (chlorpyrifos-methyl oxon and paraoxon) were most effectively catalyzed by Copper (II). The downside of catalysis using metal oxides is the formation of products with significant toxicity [22]. Badawi and Ahmed [82] noted that the hydrolysis of the pesticides diazinon, cypermethrin and carbaryl (Figure 13) was effective and accelerated by the addition of a copper (II) ion complex.

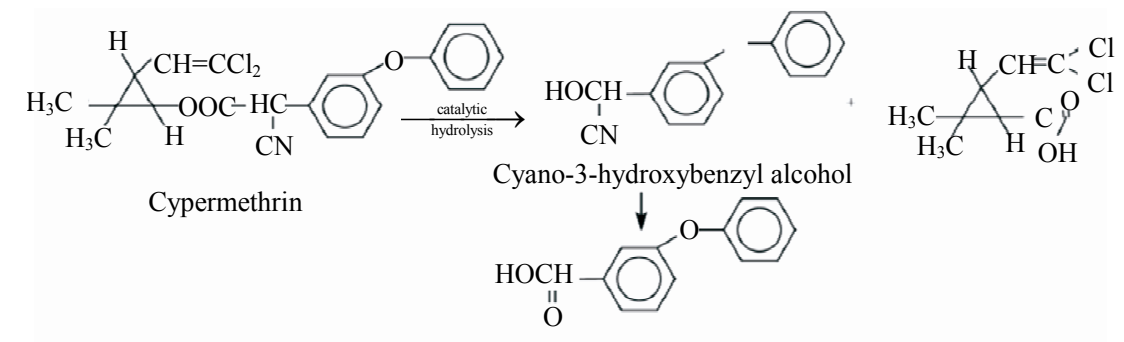<smiles>CCOc1cccc2ccccc12</smiles><smiles>C=P(S)(CCC)Oc1cc(C)nc(C(C)C)n1</smiles>

Figure 13. Hydrolysis of cypermethrin, carbaryl and diazinon pesticides [82]. 


\subsection{KPEG}

Potassium polyethylene glycol ether (KPEG) is capable of destroying chlorinated pesticides. Chlorinated hydrocarbons and cyclodienes are resistant to degradation by hydrolysis. Dechlorinating these pesticides with KPEG would then enable their biodegradation through land treatment processes. KPEG was found to be capable in dechlorinating polychlorinated biphenyls (PCBs) in soil and solvents [83,84]. In older formulations of phenoxy herbicide, KPEG was found to be capable of degrading dioxins and dibenzofurans [85]. The reaction that takes place consists of a nucleophilic substitution and a phase transfer at the carbon-halogen bond as illustrated by the following equations [22].

$$
\begin{aligned}
& \mathrm{PEG}+\mathrm{KOH} \rightarrow \mathrm{KPEG}+\mathrm{H}_{2} \mathrm{O} \\
& \mathrm{KPEG}+\mathrm{ArCln} \rightarrow \mathrm{ArCln}-1-\mathrm{PEG}+\mathrm{KCl} \\
& \mathrm{ArCln}-1-\mathrm{PEG} \rightarrow \text { ArCln-1-OH }+\mathrm{CH}_{2}=\mathrm{CH}-\mathrm{PEG}
\end{aligned}
$$

where:

PEG = polyethylene glycol monomethyl ether

$\mathrm{Ar}=$ aromatic nucleus

Taylor et al. [86] reported that the vessel for the KPE$G$ reaction consists of a 55-gal drum (surrounded with heat tape capable of maintaining the temperature at $70^{\circ} \mathrm{C}$ $-85^{\circ} \mathrm{C}$ ) and an electric motor with a mixer (Figure 14). With the reagents $\mathrm{KOH}$ and PEG, this vessel was capable of degrading $98 \%$ of phenoxy herbicide waste. The generated waste contained in the drums can remain there, eliminating the need for transfer into another container. Vapor emitted from the reaction drums are condensed in a water drum, the remaining condensables are traped in the scrubber containing sodium hypochlorite solution. Vapors are then passed through an activated carbon absorbent and as well as a molecular sieve [86].

The materials and chemicals needed for the KPEG process are easy to find [22]. The disadvantage of the KPEG process are 1) high clay content, acidity and high natural organic matter interferes with KPEG reaction and
2) its not recommended for large waste volumes with concentrations above $5 \%$ for chlorinated contaminants. If necessary, emissions can be controlled by construction of a vent system with scrubber and absorbent.

\subsection{Inorganic Absorbents}

Pesticide adsorption can be performed using anionic clays (layered double hydroxides) which are simple to prepare [87], hydrotalcite, which occurs in nature may also be used as a layered double hydroxide (LDH). A variety of compounds can be formed by changing the cation metal. In order for a material to be considered as a good adsorbent it must possess the following properties: 1) a granular structure, 2) insoluble in water, 3) chemical stability and 4) have a high mechanical strength [88]. Figure 15 is multi-functional gravity filter which can be used for various water treatment methods by employing various adsorbent media [89].

Niwas et al. [90] reported that styrene supported zirconium (IV) tungstoophosphates was successful in adsorbing the pesticide phosphamidan. Inacio et al. [86] noted that the inorganic adsorbent $\mathrm{Mg}_{3} \mathrm{AlCl}$ was capable of adsorbing the MCPA herbicide within $30-45$ minutes at room temperature. Boussahel et al. [91] noted a removal efficiency in ayanaz in and atrazine of $85 \%$ $90 \%$ using $\mathrm{CaCl}_{2}$ or $\mathrm{CaSO}_{4}$. Bojemueller et al. [92] reported that the pesticide metolachlor can be adsorbed by bentonites and the adsorption efficiency can be doubled by increasing the temperature. Li et al. [93] noted that the pesticide glyphosate was adsorbed on the external surface of MgAl-LDH at low concentrations, while at high glyphosate concentrations an inter layer ion exchange occurred.

\subsection{Organic Absorbents}

Various organic materials can be used as good adsorbents for pesticide removal. Ahmaruzzaman and Gupta [88] reported that rice husk is insoluble in water, possesses an

To Vacuum Pump

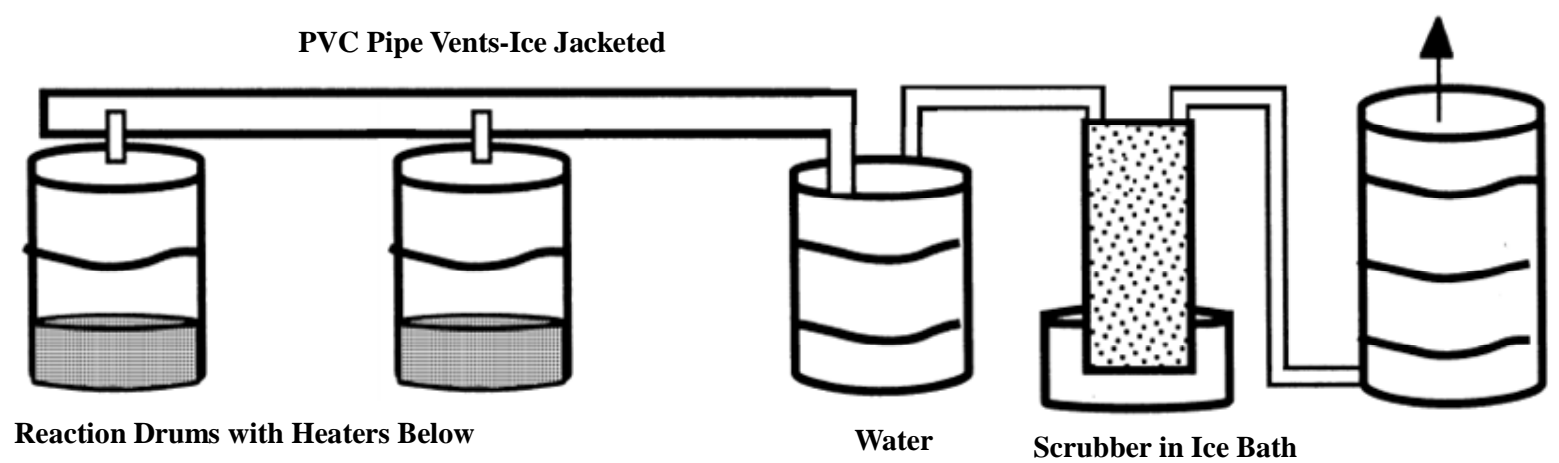

Figure 14. A KPEG process with vent system [86]. 


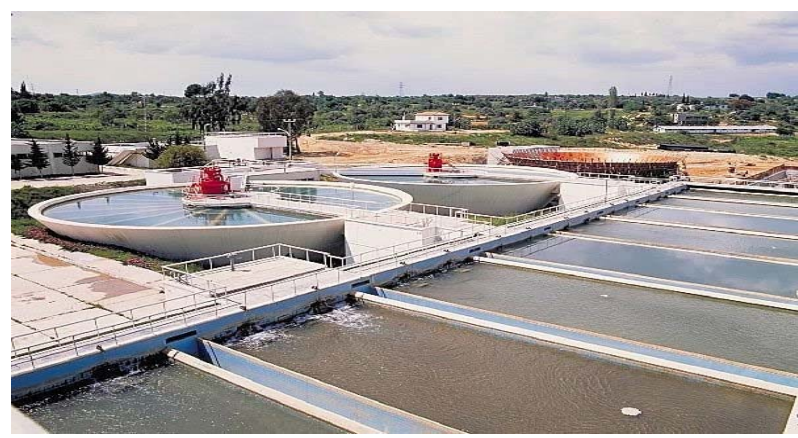

Figure 15. Filters used to treat pesticide wastewater through adsorption [89].

irregular granular structure and has a high mechanical strength and chemical stability that make it a good adsorbent. Chowdhury et al. [94] noted that treated rice husk was capable of removing $89 \%$ - $97 \%$ of malachite green pesticide. Akhtar et al. [95] investigated the adsorption potential of selected agricultural waste materials (rice, barn, bagasse fly ash from sugarcane and rice husk) for the pesticide removal of methyl parathion from wastewater and reported pesticide removal efficiencies in the range of $70 \%-90 \%$ within 90 minutes. Memon et al. [96] reported that thermally treated watermelon peels were capable of removing $99 \%$ of the methyl parathion pesticide. Al hattab and Ghaly [97] reported a captan removal efficiency of $99.2 \%$ and $98.5 \%$ using hay and soybean plant residues, respectively.

\subsection{Activated Carbon}

Carbon adsorption treatment method for pesticide containing wastewater is used in the pesticide manufacturing industry as well as in pesticide cleanup $[98,99]$. The activated carbon system consists of a prefilter made up of sand or an alum flocculation chamber with a carbon filter [100-102]. Dennis and Kobylinski [100] reported on a Carbolator (Figure 16) system which uses a suspended bed of carbon packed in bags of floating porous polyethylene in order to avoid clogging. The water was continuously recirculated through the carbon filters by directing it back into the waste holding tank.

Felsot et al. [22] reported that rinsewater containing malathion, propoxur, chlorpyifos, diaxinon and dimethoate were all removed to nondetectable levels using the Carbolator. This process reduced the amount of waste generated by several magnitudes through efficiently absorbing pesticides form the water. Kobylinski et al. [99] used a Carbulator 35B to remove baygon, dimethoate, diazinon, runnel, malathion, dursban and 2,4-D and found that the higher the molecular weight of the compound the more favourable the effect of adsorption by activated carbon. Similar findings were also reported by other researchers [104,105].

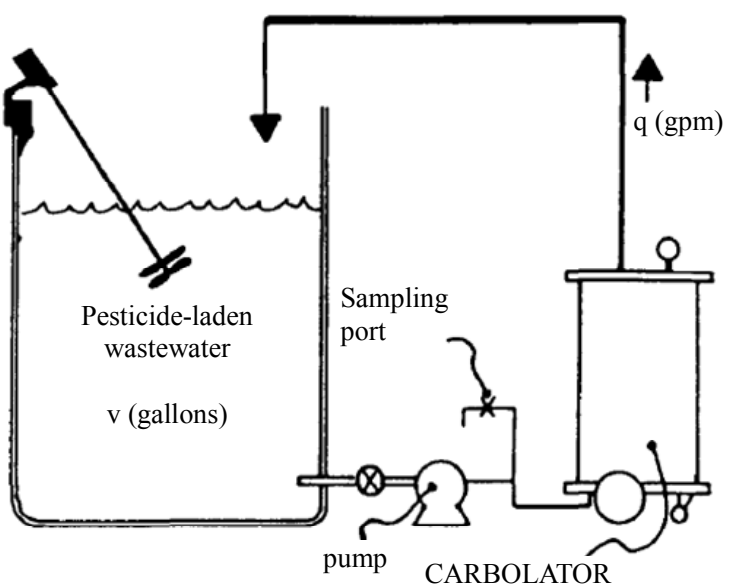

Figure 16. Recirculation through activated carbon [103].

Honeycutt et al. [69] reported that a waste stream containing $100 \mathrm{ppm}$ chlorophenols was reduced to $1 \mathrm{ppm}$ using activated carbon. Giusti et al. [106] reported a carbon activated adsorption of $3.6 \%$ and $98.5 \%$ for methanol (molecular weight of $32 \mathrm{~g} / \mathrm{mol}$ ) and 2-ethyl hexanol (molecular weight of $130.2 \mathrm{~g} / \mathrm{mol}$ ), respectively. Sarkar et al. [107] reported an adsorbent efficiency of $98 \%$ $99 \%$ for the removal of the isoproturon pesticide using powdered activated charcoal. Gupta et al. [108] reported an adsorption efficiency of $70 \%-80 \%$ using activated charcoal for removing pesticides. Word and Getzen [109] reported that a decrease in $\mathrm{pH}$ increased the adsorption of aromatic acid compounds due to enhancement of carbon surface properties.

The activated carbon is very effective in removing pesticides and it does not require extensive monitoring. The disadvantages include: 1) the need for a skilled chemist for field testing, 2) the high cost and 3) this process is only capable of adsorbing solutions with concentrations of less than $1000 \mathrm{ppm}$ [69].

\subsection{Composting}

This treatment method relies primarily on microbial activity and aeration efficiency. Microorganisms that are naturally occurring in the materials increase significantly in numbers and begin to decompose biodegradable compounds which results in the release of carbon dioxide as well as the production of metabolic heat, causing the temperature of the compost to rise to $60^{\circ} \mathrm{C}-70^{\circ} \mathrm{C}$. As the compost temperature increases, three succession of microbes occur: psycrophilis, mesophilis and thermophilis [22].

Racke and Frink [110] reported a complete degradation of carbaryl during the composting of sewage sludge. Petruska et al. [111] achieved a complete degradation of diazinon pesticide using dairy manure compost. Rose and Mercer [112] reported a $100 \%$ degradation of parathion 
insecticide in cannery wastes. Singh [113] reported a degradation efficiency of $96.03 \%$ for the endoslufin pesticide after 4 weeks, using composted soil with a moisture level of $38 \%$. Al hattab and Ghaly [97] achieved a captan removal efficiency of $92.4 \%$ in the first four days using hay compost.

Several researchers stated that polyhalogenated hydrocarbons, used in pesticides, can be metabolized under anaerobic conditions [114-117]. However, other researchers noted that pesticides may largely persist unchanged during the composting process $[110,111,118]$. Muller and Korte [118] noted little to no degradation of the aldrin, dieldrin and monolinuron during the composting of sewage waste sludge. Strom [119] noted the presence of chlordanein finished compost from various US municipalities.

\subsection{Phytoremediation}

In this method plants are used to contain and remove harmfull environmental contaminants as shown in Figure 17 [120]. Kruger et al. [121] reported a degradation efficiency in atrazine of $65 \%$ after 9 weeks in soil where Kochi sp. was planted. Coats and Anderson [122] reported that degradation of atrazine, metrolachlor and triflualin was enhanced in soils where the Kochi sp. plant grows. Olette et al. [123] reported that the aquatic plants L. minor, C. aquatic and E. Canadensis were capable of removing $2.5 \%-50 \%$ of dimethomorph and flazasulfuron present in the water. Buyanovsky et al. [124] noted that the fungi rhizosphere was capable of degrading carbofuran by using it as its carbon source. Gordon et al. [125] noted that $95 \%$ of trichloroethylene was removed from wastewater by hybrid polar trees during growing season. Stearman et al. [126] noted that in constructed wetlands, cells with plants were capable of removing $77.1 \%$ and $82.4 \%$ of simazine and metolachlor, respectively, while cells without plants were only capable of removing $64.3 \%$ and $63.2 \%$, respectively. Wang et al. [127] reported that in the first 20 days of plant growth, oilseed rape seedlings were capable of removing $20 \%$ of

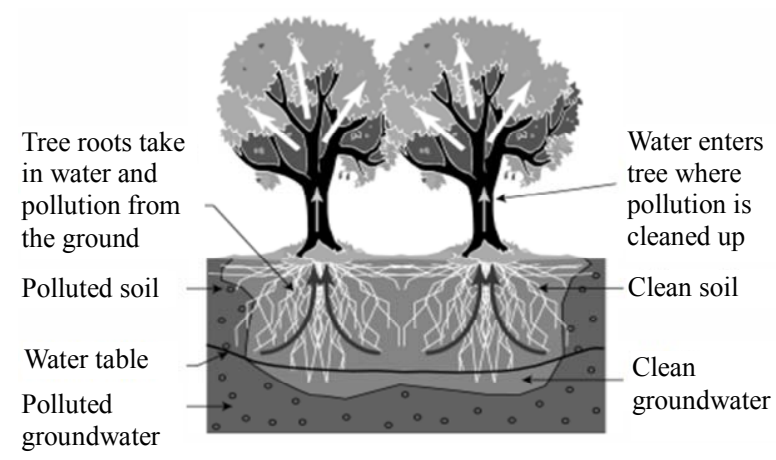

Figure 17. Phytoremediation to clean up pesticide contaminated grounds [1]. chlorpyrifos pesticide.

\subsection{Bioaugmentation}

This method uses isolated microbes for the degradation of pesticides. The pesticides are quickly metabolized and converted to products with a lower toxicity under aerobic and anaerobic conditions [22]. Some pesticides are capable of being degraded by certain bacterial strains as their sole nutrient or carbon source. Such microbial reactions are known as mineralizing because of the large amount of carbon dioxide released during metabolism [22].

Dichlorodiphenyltrichloroethane, normally resistant to biodegradation, has been reported to have been metaboilized in an anaerobic microbial culture, followed by an aerobic one [128]. Bhadhade et al. [24] reported that bacteria isolated form soil was capable of degrading $83 \%$ - $93 \%$ of the organophosphorous pesticide, monocrotophos. Ohshiro et al. [25] reported a 96\% reduction in isoxathion from the organophosphourus pestiside by bacteria isolated from turf green soil. Tang and You, [27] reported that the triazophos bacteria is capable of degrading $33.1 \%$ to $95.8 \%$ of pesticides.

The down side of such a method is the establishment of the microbes in the presence of other microbial populations present in the contaminated soil [22]. Acea et al. [129] noted that the population of the introduced bacteria may be reduced due to susceptibility to predation or starvation.

\section{Comparative Analysis}

Seven criteria (Table 7) were used for the evaluation of pesticide disposal and treatment methods: 1) containment ability, 2) detoxification ability, 3) time 4) cost, 5) suitable for on farm use, 6) size and 7) water evaporation. Each criterion was then assigned a number from 1 to 20 which was determined by the degree of importance of the criterion. These values were then used to determine the ability of each method to meet a given criterionas shown in Tables 8-25. The sum of the scores obtained from each method were then used to determine its overall performance (Table 26). The results indicated that of the 18 methods of pesticide disposal and treatment evaluated, 9 scored above 80/100 and can be used on farm. These were organic absorbents (97), composting (94), bioaugmentation (92), inorganic absorbents (90), Fenton oxidation (86) $\mathrm{O}_{3} / \mathrm{UV}(83)$, activated carbon (82), hydrolysis (82) and land cultivation (80). The other methods are not suitable for on farm use as they suffered from containment problems, high cost and variability in detoxifying effectiveness.

\section{Conclusion}

Pesticides provide the primary means for controlling 
Table 7. Criteria used in the comparative analysis.

\begin{tabular}{|c|c|c|}
\hline Criteria & Importance & Description \\
\hline Containment & 20 & $\begin{array}{l}\text { The system should be able to contain the low level pesticide wastewater with no leakage or } \\
\text { overflow so that it does not create pollution problems }\end{array}$ \\
\hline Detoxification ability & 20 & $\begin{array}{l}\text { The system should reduce the traces of pesticides by breaking the molecules down into harm- } \\
\text { less compounds }\end{array}$ \\
\hline Cost & 15 & The cost should be appealing to farmers \\
\hline Time & 15 & The rate of degradation should be faster than the rate of application \\
\hline Suitability & 12 & The system should take into consideration local climate and type of pesticides used \\
\hline Size & 10 & $\begin{array}{l}\text { An on-site method is the goal since transport is costly and requires special equipment and } \\
\text { precautions }\end{array}$ \\
\hline Evaporation & 8 & $\begin{array}{l}\text { The system should allow water to easily evaporate but not the pesticide so that clean water is } \\
\text { returned to the ecosystem }\end{array}$ \\
\hline
\end{tabular}

Table 8. Evaluation criteria for land cultivation.

\begin{tabular}{lll}
\hline Criteria & Description & Score \\
\hline Containment (20) & $\begin{array}{l}\text { Runoff will contain pesticide residues } \\
\text { Possible contamination of ground water from heavy rain or snow melt }\end{array}$ & 14 \\
Detoxification ability (20) & $\begin{array}{l}\text { Dependent on the type and concentration of pesticides } \\
\text { Relatively effective in degrading some pesticides }\end{array}$ \\
Cost (15) & $\begin{array}{l}\text { Minimum energy costs required for operation and maintenance } \\
\text { Land is radially available and economical }\end{array}$ \\
Time (15) & Dependent on the type and concentration of pesticides \\
Suitability (12) & $\begin{array}{l}\text { Effectiveness is pesticide dependant } \\
\text { System will be subjected to freeze/thaw cycles in Nova Scotia }\end{array}$ \\
Size (10) & Depends on amount of pesticide being disposed \\
Evaporation (8) & Water is absorbed by soil to provide the moisture needed for biodegradation \\
\hline
\end{tabular}

Table 9. Evaluation criteria for soil pit.

\begin{tabular}{|c|c|c|}
\hline Criteria & Description & Score \\
\hline Containment (20) & $\begin{array}{l}\text { Runoff will contain pesticide residues } \\
\text { Possible contamination of ground water after heavy rain or snow melt } \\
\text { The area needs to be fenced to prevent accidents }\end{array}$ & 12 \\
\hline Detoxification Ability (20) & $\begin{array}{l}\text { Dependent on the type and concentration of pesticides } \\
\text { High pesticide concentration may inhibit degradation }\end{array}$ & 14 \\
\hline Cost (15) & $\begin{array}{l}\text { Minimum energy cost required for operation and maintenance } \\
\text { Space and materials are available on farm }\end{array}$ & 15 \\
\hline Time (15) & Dependent on the type and concentration of pesticides & 9 \\
\hline Suitability (12) & $\begin{array}{l}\text { Effectiveness is pesticide dependent } \\
\text { System will be subject to freeze/thaw cycles in Nova Scotia }\end{array}$ & 8 \\
\hline Size (10) & Depends on amount of pesticide being disposed & 8 \\
\hline Evaporation (8) & Effective water evaporation & 6 \\
\hline
\end{tabular}


Table 10. Evaluation criteria for plastic pit.

\begin{tabular}{lll}
\hline Criteria & Description & Score \\
\hline Containment (20) & $\begin{array}{l}\text { Noted to contain pesticides satisfactorily } \\
\text { The area needs to be fenced to prevent accidents } \\
\text { Dependent on the type and concentration of pesticides } \\
\text { Reported to be very effective for 2,4-D and Carbaryl but had little effect on Atrazine } \\
\text { Costs of liner for large size pit is high } \\
\text { Commercial garbage containers are readily available and very economical }\end{array}$ & 18 \\
Cost (15) & $\begin{array}{l}\text { Dependent on the type and concentration of pesticides } \\
\text { Time (15) }\end{array}$ & $\begin{array}{l}\text { Effectiveness is pesticide dependent } \\
\text { This system will be subjected to freeze/thaw cycles in Nova Scotia and may crack }\end{array}$ \\
Suitability (12) & $\begin{array}{l}\text { Depends on amount of pesticide being disposed } \\
\text { Commercial garbage container can be used for small amounts }\end{array}$ & 12 \\
Size (10) & Effective water evaporation & 6 \\
Evaporation (8) & & 6 \\
\hline
\end{tabular}

Table 11. Evaluation criteria for concrete pit.

\begin{tabular}{lll}
\hline Criteria & Description & Score \\
\hline Containment (20) & Is more durable and will contain pesticides & 18 \\
Detoxification Ability (20) & The area needs to be fenced to prevent accidents & 18 \\
Cost (15) & Reported to be very successful with most pesticides & 9 \\
Time (15) & The cost of materials for this system is high & 10 \\
Suitability (12) & Dependent on the type and concentration of pesticides & 8 \\
Size (10) & Costly but little maintenance is required & 8 \\
Evaporation (8) & The system is subjected to freeze/thaw cycles in Nova Scotia & 6 \\
\hline
\end{tabular}

Table 12. Evaluation criteria for evaporative beds.

\begin{tabular}{|c|c|c|}
\hline Criteria & Description & Score \\
\hline Containment (20) & $\begin{array}{l}\text { Will contain pesticides } \\
\text { The area needs to be fenced to prevent accidents }\end{array}$ & 18 \\
\hline Detoxification Ability (20) & Dependent on the type and concentration of pesticides & 16 \\
\hline Cost (15) & The materials and construction are expensive & 9 \\
\hline Time (15) & Dependent on the type and concentration of pesticides & 10 \\
\hline Suitability (12) & $\begin{array}{l}\text { Costly but little maintenance is required } \\
\text { The system is subjected to freeze/thaw cycles in Nova Scotia }\end{array}$ & 8 \\
\hline Size (10) & Depends on the amount of pesticide being disposed & 8 \\
\hline Evaporation (8) & Effective water evaporation & 6 \\
\hline
\end{tabular}

Table 13. Evaluation criteria for landfilling.

\begin{tabular}{lll}
\hline Criteria & Description & Score \\
\hline Containment (20) & With proper leachate collection system this method would be adequate & 18 \\
Detoxification Ability (20) & Dependent on pesticides ability to degrade under anaerobic conditions & 12 \\
Cost (15) & Properly constructed landfills are costly & 8 \\
Time (15) & Dependent on the pesticide type and concentration & 10 \\
Suitability (12) & Suitable for all pesticides & 12 \\
Size (10) & Depends on the amount of pesticide being disposed & 8 \\
Evaporation (8) & No evaporation (used mostly for solid waste) & 8 \\
\hline
\end{tabular}


Table 14. Evaluation criteria for incineration.

\begin{tabular}{|c|c|c|}
\hline Criteria & Description & Score \\
\hline Containment (20) & $\begin{array}{l}\text { Intermediate dangerous products can be produced and emitted into the atmosphere } \\
\text { Scrubber and electrofilters can reduce emissions }\end{array}$ & 14 \\
\hline Detoxification ability (20) & $\begin{array}{l}\text { Very effective at removing the original pesticide } \\
\text { May produce other harmful products }\end{array}$ & 14 \\
\hline Cost (15) & $\begin{array}{l}\text { Very high because of the sophisticated equipment and construction involved } \\
\text { High energy consumption }\end{array}$ & 3 \\
\hline Time (15) & Rapid & 15 \\
\hline Suitability (12) & Unsuitable for on farm use because of cost and complexity & 3 \\
\hline Size (10) & Lacks standard specification for pesticides & 2 \\
\hline Evaporation (8) & Water released to atmosphere as vapor may contain some pesticide & 4 \\
\hline
\end{tabular}

Table 15. Evaluation criteria for open burning.

\begin{tabular}{ll}
\hline Criteria & Description \\
\hline Containment (20) & $\begin{array}{l}\text { Intermediate toxic products can be produced and emitted into the atmosphere } \\
\text { Must be isolated and kept away from residential areas } \\
\text { Direction of wind should be considered when choosing location } \\
\text { Temperatures for complete combustion are not reached } \\
\text { Pesticide residues still remain in the pit } \\
\text { Detoxification ability (20) }\end{array}$ \\
$\begin{array}{ll}\text { Economical } \\
\text { Cost (15) }\end{array}$ & $\begin{array}{l}\text { Relatively fast } \\
\text { Uime (15) }\end{array}$ \\
$\begin{array}{l}\text { Unitability (12) } \\
\text { Size (10) }\end{array}$ & Depends on the amount of pesticides to be disposed \\
Evaporation (8) & Water released into the atmosphere as vapour may contain pesticides \\
\hline
\end{tabular}

Table 16. Evaluation criteria for $\mathrm{O}_{3} / \mathrm{UV}$.

\begin{tabular}{lll}
\hline Criteria & Description & Score \\
\hline Containment (20) & Effective containment of pesticides & 20 \\
& $\begin{array}{l}\text { Dependent on the type and concentration of pesticides } \\
\text { Detoxification ability (20) }\end{array}$ & $\begin{array}{l}\text { Other well on aromatic compounds } \\
\text { Othe compounds maybe produced }\end{array}$ \\
Cost (15) & High equipment cost & 12 \\
Time (15) & Righ energy consumption & 8 \\
Suitability (12) & Can be used on the farm quite easily & 15 \\
Size (10) & Depends on the amount of pesticide being disposed & 12 \\
Evaporation (8) & Purified water can be recycled & 8 \\
\hline
\end{tabular}

Table 17. Evaluation criteria for Fenton oxidation.

\begin{tabular}{ll}
\hline Criteria & Description \\
\hline Containment (20) & $\begin{array}{l}\text { Effective containment of pesticides } \\
\text { Effective pesticide destruction only under acidic conditions and absence of other substances that } \\
\text { can complex with the iron ions }\end{array}$ \\
$\begin{array}{ll}\text { Letoxification ability (20) } \\
\text { Lost (15) }\end{array}$ & $\begin{array}{l}\text { Rapid if equipped with UV radiation } \\
\text { Time (15) }\end{array}$ \\
$\begin{array}{l}\text { Euitability (12) } \\
\text { Size (10) }\end{array}$ & Depends on the amount of pesticide being disposed \\
Evaporation (8) & Purified water can be recycled \\
\hline
\end{tabular}


Table 18. Evaluation criteria for hydrolysis.

\begin{tabular}{lll}
\hline Criteria & Description & Score \\
\hline Containment (20) & Effective containment of pesticides & 20 \\
Detoxification ability (20) & Effective in treating pesticides with an ester linkage & 14 \\
Cost (15) & Mable to treat chlorinated pesticides & 14 \\
Time (15) & Can be accelerated by addition of Cu(II) complex & 13 \\
Suitability (12) & Release of toxic products makes it unsuitable for on farm use & 5 \\
Size (10) & Depends on the amount of pesticide being disposed & 8 \\
Evaporation (8) & Purified water can be recycled & 8 \\
\hline
\end{tabular}

Table 19. Evaluation criteria for KEPG.

\begin{tabular}{lll}
\hline Criteria & Description & Score \\
\hline Containment (20) & $\begin{array}{l}\text { Effective if properly equipped with a vent system consisting of a scrubber and adsorbent to } \\
\text { control emissions }\end{array}$ & 16 \\
Detoxification ability (20) & $\begin{array}{l}\text { Dependent on the type and concentration of pesticides } \\
\text { Not suited for chlorinated pesticides with concentrations above } 5 \%\end{array}$ \\
Cost (15) & Materials are readily available and economical & 10 \\
Time (15) & Bergy is required & 12 \\
Suitability (12) & The ease of obtaining the chemicals required makes it suitable for farmers & 10 \\
Size (10) & Cannot be used as a remedy for large scale treatment & 5 \\
Evaporation (8) & Purified water can be recycled & 8 \\
\hline
\end{tabular}

Table 20. Evaluation criteria for inorganic absorbents.

\begin{tabular}{lll}
\hline Criteria & Description & Score \\
\hline Containment (20) & Effective containment of pesticides & 20 \\
Detoxification ability (20) & Dependent on the type and concentration of pesticides & 18 \\
Cosf (15) & Relatively economical & 12 \\
Time (15) & Faster with increased temperature & 12 \\
Suitability (12) & Materials are readily available and easy to prepare & 12 \\
Size (10) & Depends on amount of pesticides in wastewater & 8 \\
Evaporation $(8)$ & Purified water can be recycled & 8 \\
\hline
\end{tabular}

Table 21. Evaluation criteria for organic absorbents.

\begin{tabular}{lll}
\hline Criteria & Description & Score \\
\hline Containment (20) & Effective containment of pesticides & 20 \\
Detoxification ability (20) & Effective pesticide removal ability of various types & 20 \\
Cost (15) & Economical Materials are readily available & 15 \\
Time (15) & Relatively fast & 14 \\
Suitability(12) & Ease of operation makes it suitable for farmers & 12 \\
Size (10) & Depends on the amount of pesticide being disposed & 8 \\
Evaporation (8) & Purified water can be recycled & 8 \\
\hline
\end{tabular}


Table 22. Evaluation criteria for activated carbon.

\begin{tabular}{ll}
\hline Criteria & Description \\
\hline Containment (20) & Effective containment of pesticides \\
Detoxification ability (20) & Effective in treating wastewaters with pesticide concentrations less than 1000 ppm \\
Cost (15) & High cost \\
Eime (15) & Rergy is required \\
Suitability (12) & Not suitable for farmers because a skilled chemist is required for field testing \\
Size (10) & Depends on the amount of pesticide being disposed \\
Evaporation (8) & Purified water can be recycled \\
\hline
\end{tabular}

Table 23. Evaluation criteria for composting.

\begin{tabular}{ll}
\hline Criteria & Description \\
\hline Containment (20) & Effective containment if a bioreactor is used \\
Detoxification ability (20) & Effective in biodegrading pesticides \\
Cost (15) & Economical \\
Time (15) & Dependent on the pesticide type and concentration \\
Suitability (12) & The ease of operation and limited care required make this treatment option suitable for farmers \\
Size (10) & Depends on amount of pesticide being disposed \\
Evaporation (8) & Water is absorbed by the organic material to provide moisture for biodegradation \\
\hline
\end{tabular}

Table 24. Evaluation criteria for bioaugmentation.

\begin{tabular}{lll}
\hline Criteria & Description & Score \\
\hline Containment (20) & Effective containment if a bioreactor is used & 18 \\
Detoxification ability (20) & Effective in biodegrading pesticides & 20 \\
Cost (15) & Economical & 13 \\
Time (15) & Dependent on the type and concentration of pesticides & 13 \\
Suitability (12) & Can be easily used on farm sites & 12 \\
Size (10) & Depends on the amount of pesticide being disposed & 8 \\
Evaporation (8) & Water is absorbed by organic material to provide moisture for biodegradation & 8 \\
\hline
\end{tabular}

Table 25. Evaluation criteria for phytoremediation.

\begin{tabular}{|c|c|c|}
\hline Criteria & Description & Score \\
\hline Containment (20) & $\begin{array}{l}\text { Runoff will contain pesticide residues } \\
\text { The area should be fenced to avoid accidents } \\
\text { Possible contamination of ground water }\end{array}$ & 12 \\
\hline Detoxification ability (20) & Dependent on pesticide type and plant type & 12 \\
\hline Cost (15) & $\begin{array}{l}\text { Materials can be easily found } \\
\text { Relatively economical }\end{array}$ & 13 \\
\hline Time (15) & Long time is required for pesticide degradation & 8 \\
\hline Suitability (12) & The ease of operation and low cost make this method suitable for on farm use & 12 \\
\hline Size (10) & Depends on amount of pesticide being disposed & 8 \\
\hline Evaporation (8) & Effective evaporation and transevaporation & 8 \\
\hline
\end{tabular}


Table 26. Comparative analysis.

\begin{tabular}{ccccccccccccccccccc}
\hline Criteria & LC & SP & PP & CP & EB & LF & I & OB & O $3 /$ UV & FO & H & KP & IA & OA & AC & C & BA & PR \\
\hline Containment (20) & 14 & 12 & 18 & 18 & 18 & 18 & 14 & 10 & 20 & 20 & 20 & 16 & 20 & 20 & 20 & 18 & 18 & 12 \\
Detoxification ability (20) & 16 & 14 & 14 & 18 & 16 & 12 & 14 & 10 & 12 & 14 & 14 & 10 & 18 & 20 & 18 & 20 & 20 & 12 \\
Cost (15) & 15 & 15 & 12 & 9 & 9 & 8 & 3 & 13 & 8 & 11 & 14 & 12 & 12 & 15 & 9 & 15 & 13 & 13 \\
Time (15) & 10 & 10 & 10 & 10 & 10 & 10 & 15 & 13 & 15 & 13 & 13 & 10 & 12 & 14 & 13 & 13 & 13 & 8 \\
Suitability (12) & 9 & 8 & 6 & 8 & 8 & 12 & 3 & 5 & 12 & 12 & 5 & 12 & 12 & 12 & 6 & 12 & 12 & 12 \\
Size (10) & 8 & 8 & 9 & 8 & 8 & 8 & 2 & 8 & 8 & 8 & 8 & 5 & 8 & 8 & 8 & 8 & 8 & 8 \\
Evaporation (8) & 8 & 6 & 6 & 6 & 6 & 8 & 4 & 8 & 8 & 8 & 8 & 8 & 8 & 8 & 8 & 8 & 8 & 8 \\
Total (100) & $\mathbf{8 0}$ & $\mathbf{7 3}$ & $\mathbf{7 5}$ & $\mathbf{7 7}$ & $\mathbf{7 5}$ & $\mathbf{7 6}$ & $\mathbf{5 5}$ & $\mathbf{6 7}$ & $\mathbf{8 3}$ & $\mathbf{8 6}$ & $\mathbf{8 2}$ & $\mathbf{7 3}$ & $\mathbf{9 0}$ & $\mathbf{9 7}$ & $\mathbf{8 2}$ & $\mathbf{9 4}$ & $\mathbf{9 2}$ & $\mathbf{7 3}$ \\
\hline
\end{tabular}

$\mathrm{LC}=$ land cultivation; $\mathrm{FO}=$ Fenton oxidation; $\mathrm{SP}=$ soil pit; $\mathrm{H}=$ hydrolysis; $\mathrm{PP}=$ plastic pit; $\mathrm{KP}=(\mathrm{KPEG})$ potassium polyethylene glycol ether; $\mathrm{CP}=$ concrete pit; IA = inorganic adsorbents; $\mathrm{EB}=$ evaporation bed; $\mathrm{OA}=$ Organic adsorbents; $\mathrm{LF}=$ landfilling; $\mathrm{AC}=$ activated carbon; $\mathrm{I}=$ incineration; $\mathrm{C}=$ composting; $\mathrm{OB}$ $=$ open burning; $\mathrm{BA}=$ bioaugmentation; $\mathrm{O}_{3} / \mathrm{UV}=$ Ozone/Ultraviolet radiation; $\mathrm{PR}=$ phytoremediation .

organisms that compete with man for food and fibre or cause injury to man, livestock and crops. They played a vital role in the economic production of wide ranges of vegetable, fruit, cereal, forage, fibre and oil crops which now constitute a large part of successful agricultural industry in many countries. After pesticides are applied to the target areas, pesticide residues are removed from applicators by rinsing with water which results in the formation of a toxic wastewater that represents a disposal problem for many farmers. Pesticides can adversely affect people, pets, livestock and wildlife in addition to the pests they are intended to destroy. The phenomenon of biomagnification of some pesticides has resulted in reproductive failure of some fish species and egg shell thinning of birds such as peregrine falcons, sparrow hawk and eagle owls. Pesticide toxicity to humans include skin and eye irritation and skin cancer. Currently, disposal ofpesticidewastewateris carriedoutby: 1) land cultivation, 2) dumpingin soil pits, plastic pits and concrete pits or on land, and in extreme cases in streams near the rinsing operation, 3) use of evaporation beds and 4) land filling. These methods of disposal are totally unsafe as the surface run off will reach streams, rivers and lakes and theinfiltration of the wastewater into the local soil will eventually end up in the ground water. The treatment methods currently used for pesticide containing wastewater include 1) incineration (incinerators and open burning), 2) chemical treatments $\left(\mathrm{O}_{3} / \mathrm{UV}\right.$, hydrolysis, Fenton oxidation and KPEG), 3) physical treatments (inorganic absorbents, organic absorbents and activated carbon) and 4) biological treatments (composting, bio-augmentation and phytoremediation). Some of these methods either require land or are expensive and suffer from variability of effectiveness. Therefore, care must be exercised in the application, disposal and treatment of pesticides. A comparative analysis was performed on 18 methods of pesticide disposal and treatment using six criteria: containment, detoxification ability, cost, time, suitability for on farm use, size and evaporation efficiency. The results indicated that of the 18 methods evaluated, 9 scored above 80/100 and can be used on farm. These were organic absorbents (97), composting (94), bioaugmentation (89), inorganic absorbents (90), Fenton oxidation (86), $\mathrm{O}_{3} / \mathrm{UV}(83)$, activated carbon (82), hydrolysis (82) and land cultivation (80). The other methods are not suitable for on farm use as they suffered from containment problems, high cost and variability in detoxifying effectiveness.

\section{Acknowledgements}

This research was funded by the Natural Science and Engineering Research Council (NSERC) of Canada.

\section{REFERENCES}

[1] US EPA, "Pesticides and Pesticide Containers, Regulation for Acceptance and Recommended Procedures for Disposal and Treatment," US Environmental Protection Agency, Municipal Environmental Research Laboratory, Cincinnati, 2011. http://www.epa.ca

[2] WRI, "Pesticide Use (Most Recent) by Country," World Resources Institute, Woolwich, 2011. http://www.nationmaster.com

[3] AWCPN, "The World's Top 10 Pesticide Firms," Agrow World Crop Protection News, London, 2008. http://www.gmwatch.org

[4] J. K. Horowitz and E. Lichtenberg, "Insurance, Moral Hazard, and Chemical Use in Agriculture," American Journal Agricultural Economics, Vol. 75, No. 4, 1993, pp. $926-$ 935. doi:10.2307/1243980

[5] E. C. Oerke and H. W. Dehne, "Safeguarding Production-Losses in Major Crops and the Role of Crop Protection," Crop Protection, Vol. 23, No. 4, 2004, pp. 275285. doi:10.1016/j.cropro.2003.10.001

[6] J. Cooper and H. Dobson, "The Benefits of Pesticides to 
Mankind and the Environment," Crop Protection, Vol. 26 No. 9, 2007, pp. 1337-1348. doi:10.1016/i.cropro.2007.03.022

[7] C. Osteen and M. Livingstion, "Pest Management Practices," Agricultural Resources and Environmental Indicators, United States Department of Agriculture, Washington DC, 2006. http://www.ers.usda.gov

[8] T. J. Centner, "Unwanted Agricultural Pesticides: State Disposal Programs," Journal of Environmental Quality, Vol. 27, No. 4, 1998, pp. 736-742.

doi:10.2134/jeq1998.00472425002700040002x

[9] C. Wilson and C. Tisdell, "Why Farmers Continue to Use Pesticides Despite Environmental Health and Sustainability Costs," Ecological Economics, Vol. 39, No. 3, 2001, pp. 449-462. doi:10.1016/S0921-8009(01)00238-5

[10] R. L. Ridgway, J. C. Tinney, J. T. MacGregor and N. J. Starler, "Pesticide Use in Agriculture," Environmental Health Perspectives, Vol. 27, 1978, pp. 103-112. doi:10.1289/ehp.7827103

[11] D. W. Connell, "Bioaccumulation Behaviour of Persistent Organic Chemicals with Aquaticorganisms," Review of Environmental Contamination and Toxicology, Vol. 101, 1988, pp. 117-154. doi:10.1007/978-1-4612-3810-2_3

[12] K. Verschueren, "Handbook of Environmental Data on Organic Chemicals," Van Nostrand Reinhold, New York, 1977.

[13] C. E. Lundholm, "DDE-Induced Eggshell Thinning in Birds: Effects of p,p'-DDE on the Calcium and Prostaglandin Metabolism of the Eggshell Gland," Comparative Biochemistry and Physiology Part C: Pharmacology Toxicology Endocrinology, Vol. 118, No. 2, 1997, pp. 113128. doi:10.1016/S0742-8413(97)00105-9

[14] R. Spiewak, "Pesticides as a Cause of Occupational Skin Diseases in Farmers," Annals of Agricultural and Environmental Medicine, Vol. 8, No. 1, 2001, pp. 1-5.

[15] N. E. Kowal and H. R. Pahren, "Health Effects Associated with Wastewater Treatment and Disposal," Journal (Water Pollution Control Federation), Vol. 54, No. 6, 1982, pp. 677-687.

[16] W. L. Winterlin, S. R. Schoen and C. R. Mourer, "Disposal of Pesticide Wastes in Lined Evaporation Beds," Treatment and Disposal of Pesticide Wastes, Vol. 259, 1984, pp. 97-116. doi:10.1021/bk-1984-0259.ch006

[17] C. J. Somlich, M. T. Kearney and S. Elsasser, "Enhanced Soil Degradation of Alachlor by Treatment with Ultraviolet Light and Ozone," Journal of Agricultural Food Chemistry, Vol. 36, 1988, pp. 1322-1326. doi:10.1021/jf00084a049

[18] P. C. Kearney, Q. Zeng and J. M. Ruth, "A Large Scale UV-Ozonation Degradation Unit-Field Trials on Soil Pesticide Waste Disposal," ACS Symposium Series, Vol. 259, 1984, pp. 195-209.

[19] G. A. Junk, J. J. Richard and P. A. Dahm, "Degradation of Pesticides in Controlled Water-Soil Systems," Treatment of Pesticide Wastes, ACS Symposium Series, Vol. 259, 1984, pp. 125-154.

[20] C. V. Hall, J. Baker, P. Dahm, L. Freiburger and G. Gorder, "Safe Disposal Methods for Agricultural Pesticide
Wastes," US Environmental Protection Agency, Municipal Environmental Research Laboratory, Cincinnati, 1981. http://www.epa.gov/

[21] FRTR, "Composting (ex Situ Biological Treatment)," Federal Remediation Technologies Roundtable, Center for Environmental Research Information, Cincinnati, 2008. http://www.frtr.gov/matrix $/$ section4/4-12.html

[22] A. S. Felsot, K. D. Racke and D. J. Hamilton, "Disposal and Degradation of Pesticide Waste," Reviews of Environmental Contamination and Toxicology, Vol. 177, 2003, pp. 123-200. doi:10.1007/0-387-21725-8_3

[23] R. F. Krueger and D. J. Severn, "Regulation of Pesticide Disposal," Treatment and Disposal of Pesticide Wastes, ACS Symposium Series, Vol. 259, 1984, pp. 3-15. doi:10.1021/bk-1984-0259.ch001

[24] B. J. Bhadhade, S. S. Sarnaik and P. P. Kanekar, "Bioremediation of an Industrial Effluent Containing Monocrotophos," Current Microbiology, Vol. 45, No. 5, 2002, pp. 346-349. doi:10.1007/s00284-002-3681-1

[25] K. Ohshiro, T. Kakuta, T. Sakai, H. Hirota, T. Hoshino and T. Uchiyama, "Biodegradtion of Organophosphorus Insecticides by Bacteria Isolated from Turf Green Soil," Journal of Fermentation and Bioengineering, Vol. 82, No. 3, 1996, pp. 299-305. doi:10.1016/0922-338X(96)88823-4

[26] P. C. Kearney, R. G. Nash and C. S. Helling, "Pesticide Degradation Properties," Proceedings, National Workshop on Pesticide Waste Disposal, US Environmental Protection Agency, Water Engineering Research Laboratory, Cincinnati, 1985, pp. 35-42.

[27] M. Tang and M. You, "Isolation, Identification and Characterization of a Novel Triazophos-Degrading Bacillus sp. (TAP-1)," Microbiological Research, Vol. 167, No. 5, pp. 299-305. doi:10.1016/j.micres.2011.10.004

[28] K. D. Racke and J. R. Coats, "Enhanced Biodegradation of Pesticides in the Environment," American Chemical Society, No. 426, Washington DC, 1990.

[29] R. S. Schoen and W. L. Winterlin, "The Effects of Various Soil Factors and Amendments on the Degradation of Pesticide Mixtures," Journal of Environmental Science and Health Part B, Vol. 22, No. 3, 1987, pp. 347-377. doi:10.1080/03601238709372561

[30] A. S. Felsot, "Landfarming Pesticide-Contaminated Soils," Pesticide Remediation in Soils and Water, Wiley, New York, 1998, pp. 129-160.

[31] L. Somasundaram, J. R. Coats, D. K. Racke and H. M. Stahr, "Application of the Microtox System to Assess the Toxicity of Pesticides and Their Hydrolysis Metabolites," Bulletin of Environmental Contamination Toxicology, Vol. 44, No. 2, 1990, pp. 254-259. doi:10.1007/BF01700144

[32] A. S. Felsot, J. K. Mitchell and E. K. Dzantor, "Remediation of Herbicide Contaminated Soil by Combinations of Landfarming and Biostimulation," SSSA Special Publication, Vol. 43, 1995, pp. 237-257.

[33] W. Winterlin, J. N. Seiber, A. Craigmill, T. Baier, J. Woodrow and G. Walker, "Degradation of Pesticide Waste Taken from a Highly Contaminated Soil Evaporation Pit in California," Archives of Environmental Contamination 
and Toxicology, Vol. 18, 1989, pp. 734-747. doi:10.1007/BF01225011

[34] J. Y. Gan and W. C. Koskinen, "Pesticide Fate and Behavior in Soil at Elevated Concentrations," In: P. C. Kearney and T. R. Roberts, Eds., Pesticide Remediation in Soils and Water, Wiley, Chichester, 1998, pp. 59-84.

[35] E. K. Dzantor and A. S. Felsot, "Microbial Responses to Large Concentrations of Herbicides in Soil," Environmental Toxicology and Chemistry, Vol. 10, No. 5, 1991, pp. 649-655. doi:10.1002/etc.5620100511

[36] J. Gan, W. C. Koskinen, R. L. Becker and D. D. Buhler, "Effect of Concentration on Persistence of Alachlor in Soil," Journal of Environmental Quality, Vol. 24, No. 6, 1995, pp. 1162-1169. doi:10.2134/jeq1995.00472425002400060016x

[37] J. M. Davidson, P. S. Rao, L. T. Ou, W. B. Wheeler and D. F. Rothwell, "Adsorption, Movement and Biological Degradation of Large Concentrations of Selected Pesticides in Soil," US Environmental Protection Agency, Municipal Environmental Research Laboratory, Cincinnati, 1980.

[38] J. Gan, R. L. Becker, W. C. Koskinen and D. D. Buhler, "Degradation of Atrazine in Two Soils as a Function of Concentration," Journal of Environmental Quality, Vol. 25, No. 5, 1996, pp. 1064-1072. doi:10.2134/jeq1996.00472425002500050019x

[39] G. A. Junk and J. J. Richard, "Pesticide Disposal Sites: Sampling and Analysis," ACS Symposium Series, Vol. 259, 1984, pp. 69-95.

[40] B. Kinnear, "Wastewater Technology: Engineering a Healthier Society," University of Southern California, Los Angeles, 2011. http://www.illumin.usc.edu

[41] L. M. Johnson and P. A. Hartman, "Microbiology of a Pesticide Disposal Pit," Bulletin of Environmental Contamination and Toxicology, Vol. 25, No. 3, 1980, pp. 448455. doi:10.1007/BF01985553

[42] C. V. Hall, "Pesticide Waste Disposal in Agriculture," Treatment and Disposal of Pesticide Wastes, Vol. 3, 1984, pp. 27-36. doi:10.1021/bk-1984-0259.ch003

[43] LANL, "Aerial Tour of Los Alamos National Laboratory," Los Alamos Study Group, Albuquerque, 2004. http://www.lasg.org

[44] D. M. Hodapp and W. Winterlin, "Pesticide Degradation in Model Soil Evaporation Beds," Bulletin of Environmental Contamination and Toxicology, Vol. 43, No. 1, 1989, pp. 36-44. doi:10.1007/BF01702235

[45] B. Plumer, "The Cost of Superfund Neglect," The New Republic, Washington DC, 2006. http://www.plumer.blogspot.com

[46] KPBSWD, "Central Peninsula Landfill," Solid Waste Department, Kenai Peninsula Borough Solid Waste Department, Soldotna, 2011. http://www2.borough.kenai.ak.us/solidwaste/

[47] M. Ghassami, S. C. Quinlivan and H. R. Day, "Landfills for Pesticide Waste Disposal," Environmental Science and Technology, Vol. 10, No. 13, 1976, pp. 1209-1214. doi:10.1021/es60123a005
[48] P. Truong and B. Hart, "Vetiver System for Wastewater Treatment," Pacific Rim Vetiver Network Technical Bulletin, San Antonio, 2000. http://www.vetiver.org

[49] D. M. Munnecke, "Enzymic Detoxification of Waste Organophosphate Pesticides," Journal of Agricultural and Food Chemistry, Vol. 28, No. 1, 1980, pp. 105-111. doi: $10.1021 / \mathrm{jf} 60227 \mathrm{a} 025$

[50] W. G. Johnson and T. L. Lavy, "In-Situ Dissipation of Benymyl, Carbofuran, Thiobencarb and Triclopyr at Three Soil Depths," Journal of Environmental Quality, Vol. 23, No. 3, 1994, pp. 556-562. doi:10.2134/jeq1994.00472425002300030022x

[51] A. Yasuhara, H. Shiraishi, M. Nishikawa, T. Yamamoto, T. Uehiro, O. Nakasugi, T. Okumura, K. Kenmotsu, H. Fukui, M. Nagase, Y. Ono, Y. Kawagoshi, K. Baba and Y. Noma, "Determination of Organic Components in Leachates from Hazardous Waste Disposal Sites in Japan by Gas Chromatography-Mass Spectrometry," Journal of Chromatograohy A, Vol. 774, No. 1, 1997, pp. 321-332.

[52] G. M. Williams, I. Harrison, C. A. Carlick and O. Crowley, "Changes in Anantipmeric Fraction as Evidence of Natural Attenuation of Mecoprop in a Limestone Aquifer," Journal of Contaminant Hydrology, Vol. 64, No. 3-4, 2003, pp. 253-267. doi:10.1016/S0169-7722(02)00206-1

[53] T. H. Christensen, P. Kjeldsen, P. L. Bjerg, D. L. Jensen, J. B. Christensen, A. Baun, H. J. Albrechtsen and G. Heron, "Biogeochemistry of Landfill Leachate Plumes," Applied Geochemistry, Vol. 16, No. 7, 2001, pp. 659-718. doi:10.1016/S0883-2927(00)00082-2

[54] B. J. Alloway and D. C. Ayres, "Chemical Principles of Environmental Pollution," Water, Air and Soil Pollution, Vol. 102, No. 3, 1997, pp. 216-218.

[55] T. L. Ferguson and R. R. Wilkinson, "Incineration of Pesticide Wastes," Treatment and Disposal of Pesticide Wastes, ACS Symposium Series, Vol. 259, 1984, pp. 181191.

[56] D. A. Oberacker, "Incineration Options for Disposal of Waste Pesticides," In: J. S. Bridges and C. R. Dempsey, Eds., Pesticide Waste Disposal Technology, US Environmental Protection Agency, Noyes Data Corporation, 1988.

[57] M. V. Kennedy, B. J. Stojanovic and F. L. Shuman, "Chemical and Thermal Methods for Disposal of Pesticides," Residue Reviews, Vol. 29, 1969, pp. 89-104.

[58] E. M. Steverson, "Incineration as a Pesticide Remediation Method," Pesticide Remediation in Soils and Water, Wiley, New York, 1998, pp. 85-103.

[59] W. P. Linak, J. A. Mulholland, J. A. McSorley, R. E. Hall, R. K. Srivastava, J. V. Ryan, M. G. Nishioka, J. Lewtas and D. M. DeMarini, "Application of Staged Combustion and Reburning to the Co-Firing of Nitrogen-Containing Wastes," Hazardous Waste and Hazardous Materials, Vol. 8, No. 1, 1991, pp. 1-15. doi:10.1089/hwm.1991.8.1

[60] B. Ahling and K. Wiberger, "Incineration of Pesticides Containing Phosphorus," Journal of Environmental Quality, Vol. 8, No. 1, 1979, pp. 12-13. doi:10.2134/jeq1979.00472425000800010003x

[61] J. J. Santoleri, "Incineration,” Pollution Issues, Advameg, Flossmoor, 2011. 
http://www.pollutionissues.com/Ho-Li/Incineration.html

[62] CART, "Allowable Open Burning," Country Acres Resource Team, Adams County Extension, Brighton, 2008. http://www.coopext.colostate.edu/adams/sa/openburning. htm

[63] B. Adebona, A. Shafagati, E. J. Martin and R. C. Chawla, "Laboratory Evaluation of Products of Incomplete Combustion Formed from Burning of Agricultural Product Bags," Waste Management, ACS Symposium Series, Vol. 510, 1992, pp. 63-77.

[64] D. A. Oberacker, P. C. Lin, G. M. Shaul, D. T. Ferguson, V. S. Engleman, T. W. Jackson, J. S. Chapman, J. D. Evans, R. J. Martrano and L. L. Every, "Characterization of Emissions Formed from Open Burning of Pesticide Bags," Pesticide Waste Management, ACS Symposium Series, Vol. 510, 1992, pp. 78-94.

[65] A. Mokrini, D. Oussi and S. Esplugas, "Oxidaiton of Aromatic Compounds with UV Radiation/Ozone/Hydrogen Peroxide," Water Science and Technology, Vol. 35, No. 4, 1981, pp. 95-102. doi:10.1016/S0273-1223(97)00014-0

[66] W. H. Glaze, "Drinking-Water Treatment with Ozone," Environmental Science and Technology, Vol. 21, No. 3, 1987, pp. 224-230. doi:10.1021/es00157a001

[67] G. R. Peyton and W. H. Glaze, "Mechanism of Photolytic Ozonation," Photochemistry of Environmental Aquatic Systems, ACS Symposium Series, Vol. 327, 1987, pp. 76-88.

[68] W. S. Kuo, "Photocatalytic Oxidation of Pesticide Rinsate," Journal of Environmental Science and Health, Part B: Pesticides, Food Contaminants, and Agricultural Wastes, Vol. 37, No. 1, 2002, pp. 65-74. doi:10.1081/PFC-120002898

[69] R. D. H. Paulson, H. LeBaron, G. Rolofson and C. Ganz, "Chemical Treatment Options for Pesticide Wastes Disposal," In: J. S. Bridges and C. R. Dempsey, Eds., Pesticide Waste Disposal Technology, Park Ridge, 1988, pp. 73-86.

[70] H. Fallmann, T. Krutzler, R. Bauer, S. Malato and J. Blanco, "Applicability of the Photo-Fenton Method for Treating Water Containing Pesticides," Catalysis Today, Vol. 54, No. 2-3, 1999, pp. 309-319. doi:10.1016/S0920-5861(99)00192-3

[71] Y. Sun and J. J. Pingnatello, "Chemical Treatment of Pesticide Wastes, Evaluation of Fe(III) Chelates for Catalytic Hydrogen Peroxide Oxidation of 2,4-D at Circumneutral pH," Journal of Agricultural Food Chemistry, Vol. 40, 1992, pp. 322-327. doi:10.1021/jf00014a031

[72] C. Ozdemir, S. Sahinkaya and M. Onucyildiz, "Treatment of Pesticide Wastewater by Physiochemical and Fenton Processes," Asian Journal of Chemistry, Vol. 20, No. 5, 2008, pp. 3795-3804.

[73] S. Malato, J. Blanco, A. Vidal, P. Fernandez, J. Caceres, P. Trincado, J. C. Oliveira and M. Vincent, "New Large Solar Photocatalytic Plant: Set-Up and Preliminary Results," Chemosphere, Vol. 47, No. 3, 2002, pp. 235-240. doi:10.1016/S0045-6535(01)00220-X

[74] R. A. Larson, M. B. Schlauch and K. A. Marley, "Ferric Ion Promoted Photodecomposition or Trizines," Journal of Agricultural Food Chemistry, Vol. 39, No. 11, 1991, pp. 2057-2062. doi:10.1021/jf00011a035

[75] P. L. Huston and J. J. Pignatello, "Degradation of Selected Pesticide Active Ingredients and Commercial Formulations in Water by the Photo-Assisted Fenton Reaction," Water Research, Vol. 33, No. 5, 1999, pp. 12381246. doi:10.1016/S0043-1354(98)00330-3

[76] J. J. Pignatello and Y. Sun, “Complete Oxidation of Metolachlor and Methyl Parathion in Water by the Photoassisted Fenton Reaction," Water Research, Vol. 29, 1995, pp. 1837-1844. doi:10.1016/0043-1354(94)00352-8

[77] R. Doong and W. Chang, "Photoassisted Iron Compound Catalytic Degradation of Organophosphorous Pesticide with Hydrogen Peroxide," Chemosphere, Vol. 37, No. 13, 1998 , pp. 2563-2572. doi:10.1016/S0045-6535(98)00038-1

[78] J. M. Desmarchelier, "Kinetics of Alkaline and PeroxideCatalyzed Hydrolysis of Fenitrothion," Journal of Environmental Science and Health, Part B, Vol. 22, No. 4, 1987, pp. 403-411.

[79] G. Lee, R. A. Kenley and J. S. Winterle, "Reaction of Sodium Perborate with Organophosphorus Esters," Treatment and Disposal of Pesticide Wastes, ACS Symposium Series, Vol. 259, 1984, pp. 211-219.

[80] C. Qian, P. G. Sanders and J. N. Seiber, “Accelerated Degradation of Organophosphorus Pesticides with Sodium Perborate," Bulletin of Environmental Contamination and Toxicology, Vol. 35, No. 1, 1985, pp. 682-688. doi:10.1007/BF01636573

[81] J. M. Smolen and A. T. Stone, "Divalent Metal IonCatalyzed Hydrolysis of Phosphorothionate Ester Pesticides and Their Corresponding Oxonated," Environmental Science and Technology, Vol. 31, No. 6, 1997, pp. 16641673. doi:10.1021/es960499q

[82] A. M. Badawi and S. M. Ahmed, "Hydrolysis of Pesticides in Wastewater Catalyzed by $\mathrm{Cu}(\mathrm{II})$ Complexes of Silyl Based Cationic Micelles," Journal of Dispersion Science and Technology, Vol. 31, No. 4, 2010, pp. 577582. doi:10.1080/01932690903192804

[83] D. J. Brunelle and D. A. Singleton, "Chemical Reaction of Polychlorinated Biphenyls on Soils with Poly(Ethylene glycol)/KOH," Chemosphere, Vol. 14, No. 2, 1985, pp. 173-181. doi:10.1016/0045-6535(85)90096-7

[84] A. Kornel and C. J. Rogers, "PCB Destruction: A Novel Dehalogenation Reagent," Journal of Hazardous Materials, Vol. 12, No. 2, 1985, pp. 161-176. doi:10.1016/0304-3894(85)85004-4

[85] T. O. Tiernan, D. J. Wagel, J. H. Garrett, G. F. VanNess, J.G. Solch and L. A. Harden, "Laboratory and Field Tests to Demonstrate the Efficacy of KPEG Reagent for Detoxification of Hazardous Wastes Containing Polychlorinated Dibenzo-p-Dioxins (PCDD) and Dibenzofurans (PCDF) and Soils Contaminated with Such Chemical Wastes," Chemosphere, Vol. 18, 1989, pp. 835-841. doi:10.1016/0045-6535(89)90205-1

[86] M. L. Taylor, J. A. Wentz, M. A. Dosani, W. Gallagher and J. S. Greber, "Treating Chlorinated Wastes with KPEG Process," US Environmental Protection Agency, Engineering Laboratory, Cincinnati, 1990. 
[87] J. Inacio, C. Taviot-Gueho, C. Forano and J. P. Besse, "Adsorption of MCPA Pesticide by MgAl-Layered Double Hydroxides," Applied Clay Science, Vol. 18, No. 5-6, 2001, pp. 255-264. doi:10.1016/S0169-1317(01)00029-1

[88] M. Ahmaruzzaman and V. K. Gupta, "Rice Husk and Its Ash as Low-Cost Adsorbents in Water and Wastewater Treatment," Industrial and Engineering Chemistry Research, Vol. 50, No. 24, 2011, pp. 13589-13613.

[89] VWST, "Gravity Filter," Veolia Water Solutions and Technology, Saint Maurice, 2011.

http://www.veoliawaterst.com/filtraflo/en/

[90] R. Niwas, U. Gupta, A. A. Khan and K. G. Varshney, "The Absorption of Phosphamidon on the Surface of Styrene Supported Zirconium (IV) Tungstophosphate: A Thermodynamic Study," Colloids and Surfaces, A: Physicochemical and Engineering Aspects, Vol. 164, 2000, pp. 115-119. doi:10.1016/S0927-7757(99)00247-2

[91] R. Boussahel, A. Montiel and M. Baudu, "Effects of Organic and Inorganic Matter on Pesticide Rejection by Nanofiltration," Desalination, Vol. 145, No. 1, 2002, pp. 109-114. doi:10.1016/S0011-9164(02)00394-6

[92] E. Bojemueller, A. Nennemann and G. Lagaly, "Enhanced Pesticide Adsorption by Thermally Modified Bentonites," Applied Clay Science, Vol. 18, No. 5-6, 2001, pp. 277284. doi:10.1016/S0169-1317(01)00027-8

[93] F. Li, Y. Wang, Q. Yang, D. G. Evans, C. Forano and X. Duan, "Study on Adsorption of Glyphosate (N-Phosphonomethyl Glycine) Pesticide on MgAl-Layered Double Hydroxides in Aqueous Solution," Journal of Hazardous Materials, Vol. 125, No. 1-3, 2005, pp. 89-95. doi:10.1016/j.jhazmat.2005.04.037

[94] S. Chowdhury, R. Mishra, P. Saha and P. Kushwaha, "Adsorption Thermodynamics, Kinetics and Isosteric Heat of Adsorption of Malachite Green onto Chemically Modified Rice Husk," Desalination, Vol. 265, No. 1, 2011, pp. 159-168. doi:10.1016/j.desal.2010.07.047

[95] M. Akhtar, S. M. Hasany, M. I. Bhanger and S. Iqbal, "Low Cost Sorbents for the Removal of Methyl Parathion Pesticide from Aqueous Solutions," Chemosphere, Vol. 66, No. 10, 2007, pp. 1829-1838. doi:10.1016/j.chemosphere.2006.09.006

[96] G. Z. Memon, M. I. Bhanger, M. Akhtar, F. N. Talpur and J. R. Memon, "Adsorption of Methyl Parathion Pesticide from Water Using Watermelon Peels as a Low Cost Adsorbent," Chemical Engineering Journal, Vol. 138, No. 1-3, 2008, pp. 616-621. doi:10.1016/j.cej.2007.09.027

[97] M. Al hattab and A. E. Ghaly, "Sequential Remediation Processes for Low Level Pesticide Wastewater," Journal of Environmental Protection, Vol. 3, No. 2, 2012, pp. 150163. doi:10.4236/jep.2012.32019

[98] P. R. Atkins, “The Pesticide Manufacturing Industry-Current Waste Treatment and Disposal Practices," Water Pollution Control Research Series, US Environmental Protection Agency, Washington DC, 1972.

[99] E. A. Kobylinski, W. H. Dennis and A. B. Rosencrance, "Treatment of Pesticide-Laden Waste Water by Recirculation through Activated Carbon," Treatment of Pesticide Wastes, ACS Symposium Series, Vol. 259, 1984, pp. 125154.
[100] W. H. Dennis and E. A. Kobylinski, "Pesticide-Laden Wastewater Treatment for Small Waste Generators," Journal of Environmental Science and Health, Part B: Pesticides, Food Contaminants, and Agricultural Wastes, Vol. 18, No. 3, 1983, pp. 317-331. doi:10.1080/03601238309372372

[101] J. C. Nye, "Treating Pesticide-Contaminated Wastewater, Development and Evaluation of a System," Treatment and Disposal of Pesticide Wastes, ACS Symposium Series, Vol. 259, 1984, pp. 153-160.

[102] S. E. Dwinell, "Treatment of Pesticide Wastes: Regulatory and Operational Requirements for Successful Treatment Systems," Pesticide Waste Management, ACS Symposium Series, Vol. 510, 1992, pp. 113-126. doi:10.1021/bk-1992-0510.ch009

[103] W. H. Dennis, "A Practical System to Treat PesticideLaden Wastewater," Proceedings: National Workshop on Pesticide Waste Disposal, US Environmental Protection Agency, Denver, 1985.

[104] J. C. Morris and W. J. Weber Jr., "Adsorption of Biochemically Resistant Materials form Solution," Advanced Waste Treatment Research Program, US Public Health Service, Cincinnati, 1964, AWTR-9 Report 999-WP-11

[105] J. C. Morris and J. Weber Jr., "Adsorption of Biochemically Resistant Materials Form Solution," Part II, US Public Health Service, Advanced Waste Treatment Research Program, Cincinnati, 1966, WTR-16, Report 999 $\mathrm{P}-33$.

[106] D. M. Giusti, R. A. Conway and C. T. Lawson, "Activated Carbon Adsorption of Petrochemicals," Journal-Water Pollution Control Federation, Vol. 46, No. 5, pp. $1974947-$ 1974965

[107] B. Sarkar, N. Venkateswralu, R. N. Rao and C. Bhattacharjee, "Treatment of Pesticide Contaminated Surface Water for Production of Potable Water by a CoagulationAdsorption-Nanofiltration Approach," Desalination, Vol. 212, No. 1-3, 2007, pp. 129-140. doi:10.1016/j.desal.2006.09.021

[108] V. K. Gupta, I. Ali Suhas and V. K. Saini, “Adsorption of 2,4-D and Carbofuran Pesticides Using Fertilizer and Steel Industry Wastes," Journal of Colloid and Interface Science, Vol. 299, No. 2, 2006, pp. 556-563. doi:10.1016/j.jcis.2006.02.017

[109] T. M. Word and F. W. Getzen, "Influence of pH on the Adsorption of Aromatic Acids on Activated Carbon," Environmental Science and Technology, Vol. 4, No. 1, 1970, pp. 64-67. doi:10.1021/es60036a006

[110] K. D. Racke and C. R. Frink, "Fate of Organic Contaminants during Sewage Sludge Composting," Bulletin of Environmental Contamination and Toxicology, Vol. 42, No. 4, 1989, pp. 526-533. doi:10.1007/BF01700232

[111] J. A. Petruska, D. E. Mullins, R. W. Young and E. R. Collins, "A Benchtop System for Evaluation of Pesticide Disposal by Composting," Nuclear and Chemical Waste Management, Vol. 5, No. 3, 1985, pp. 177-182. doi:10.1016/0191-815X(85)90076-2

[112] W. W. Rose and W. A. Mercer, "Fate of Insecticides in Composting Agricultural Wastes. Fate of Pesticides in Composted Agricultural Wastes," National Canners As- 
sociation, Washington DC, 1968.

[113] D. K. Singh, "Biodegradation and Bioremediation of Pesticide in Soil: Concept, Method and Recent Developments," Biodegradation, Vol. 48, 2008, pp. 35-50.

[114] T. F. Castro and T. Yoshida, "Effect of Organic Matter on the Biodegradation of Some Organochlorine Insecticides in Submerged Soils," Soil Science and Plant Nutrition, Vol. 20, No. 4, 1974, pp. 363-370. doi:10.1080/00380768.1974.10432607

[115] J. F. Brown, R. E. Wagner, H. Feng, D. L. Bedard, M. J. Brennan, J. C. Carnahan and R. J. May, "Environmental Dechlorination of PCBs," Environmental Toxicology and Chemistry, Vol. 6, No. 8, 1987, pp. 579-593. doi:10.1002/etc.5620060802

[116] P. Adriaens, Q. Fu and D. Grbic-Galic, "Bioavailability and Transformation of Highly Chlorinated Dibenzo-pDioxins and Dibenzofurans in Anaerobic Soils and Sediments," Environmental Science and Technology, Vol. 29, No. 9, 1995, pp. 2252-2260. doi:10.1021/es00009a015

[117] M. J. Zwiernik, J. F. Quensen and S. A. Boyd, "FeSO Amendments Stimulate Extensive Anaerobic PCB Dechlorination," Environmental Science and Technology, Vol. 32, No. 21, 1998, pp. 3360-3365. doi:10.1021/es9801689

[118] W. P. Muller and F. Korte, "Ecological Chemical Evaluation of Waste Treatment Procedures," Environmental Quality and Safety, Vol. 5, 1976, pp. 215-236.

[119] P. F. Strom, "Pesticides in Yard Waste Compost," Compost Science and Utilization, Vol. 8, No. 1, 2000, pp. 5460.

[120] S. D. Cunningham, T. A. Anderson, P. A. Schwab and F. C. Hsu, "Phytoremediation of Soils Contaminated with Organic Pollutants," Advances in Agronomy, Vol. 56, 1996, pp. 55-114. doi:10.1016/S0065-2113(08)60179-0

[121] E. L. Kruger, T. A. Anderson and J. R. Coats, "Phytoremediation of Soil and Water Contaminants," ACS Symmposium Series, Vol. 664, 1997, pp. 1-4.

[122] J. R. Coats and T. A. Anderson, "The Use of Vegetation to Enhance Bioremediation of Surface Soils Contaminated with Pesticide Wastes," US Environmental Protection Agency, Office of Research and Development, Washington DC, 1997. http://www.epa.gov/

[123] R. Olette, M. Couderchet, S. Biagianti and P. Eullaffroy, "Toxicity and Removal of Pesticides by Selected Aquatic Plants," Chemosphere, Vol. 70, No. 8, 2008, pp. 14141421. doi:10.1016/j.chemosphere.2007.09.016

[124] G. A. Buyanovsky, R. J. Kremer, A. M. Gajda and H. V. Kazemi, "Effect of corn Plants And Rhizosphere Populations on Pesticide Degradation," Bulletin of Environmental Contamination and Toxicology, Vol. 55, 1995, pp. 689-696. doi:10.1007/BF00203754

[125] M. Gordon, N. Choe, J. Duffy, G. Ekuan, P. Heilman, I. Muiznieks, M. Ruszaj, B. B. Shurtleff, S. Strand, J. Wilmoth and L. A. Newman, "Phytoremediaiton of Trichloroethylene with Hybrid Poplars," Environmental Health Perspectives Supplements, Vol. 106, No. 4, 1998, pp. 10011004. doi:10.1289/ehp.98106s41001

[126] K. Stearman, D. George, K. Carlson and S. Lansford, "Pesticide Removal from Container Nursery Runoff in Constructed Wetland Cells," Journal of Environmental Quality, Vol. 32, No. 4, 2003, pp. 1548-1556. doi: $10.2134 /$ jeq2003.1548

[127] L. Wang, X. Jiang, D. Yan, J. Wu, Y. Bian and F. Wang, "Behavior and Fate of Chlorpyrifos Introduced into SoilCrop Systems by Irrigation," Chemosphere, Vol. 66, No. 3, 2007, pp. 391-396. doi:10.1016/i.chemosphere.2006.06.038

[128]F. K. Pfaender and M. Alexander, "Extensive Microbial Degradation of DDT in Vitro and DDT Metabolism by Natural Communities," Journal of Agricultural Food Chemistry, Vol. 20, No. 4, 1972, pp. 842-846. doi:10.1021/jf60182a045

[129] M. J. Acea, C. R. Moore and M. Alexander, "Survival and Growth of Bacteria Introduced into Soil," Soil Biology and Biochemistry, Vol. 20, No. 4, 1988, pp. 509-515. doi:10.1016/0038-0717(88)90066-1 